\title{
The Quaternary glacial history of Nanga Parbat
}

\author{
Lewis A. Owen ${ }^{\mathrm{a}, *}$, Christine H. Scott ${ }^{\mathrm{b}}$, Edward Derbyshire ${ }^{\mathrm{c}}$ \\ ${ }^{a}$ Department of Earth Sciences, University of California, Riverside, CA 92521-0423, USA \\ ${ }^{\mathrm{b}}$ Department of Geography, University of Leicester, Leicester LE1 7RH, UK \\ ${ }^{\mathrm{c}}$ Department of Geography, Royal Holloway, University of London, Egham Surrey, TW20 OEX, UK
}

\begin{abstract}
During one or more times throughout the Quaternary, an extensive glacier system occupied the valleys of the Nanga Parbat massif. Glacial landforms in the Astor valley provide evidence for two separate glacial advances with ice advancing more than $15 \mathrm{~km}$ down-valley from the present ice fronts. Elsewhere in the massif, geomorphic and sedimentological evidence provide evidence for a less extensive glaciation, where glaciers advanced no more than $12 \mathrm{~km}$ beyond their present positions. Intense erosion and mass movement has destroyed any depositional evidence for earlier Pleistocene glaciations. However, truncated spurs, hanging valleys, steep valley sides and over-deepened trunk valleys provide evidence of an earlier, more extensive glaciation. Small moraines near the snouts of the present glaciers provide evidence for at least three limited glacial advances that post-date the extensive valley glacier system. On the basis of geomorphology, sedimentology and relative weathering characteristics glacial landforms are correlated across the Nanga Parbat massif. Furthermore, the age of the maximum extent of valley glaciation is tentatively assigned to early in the last glacial cycle with two late Pleistocene readvances or periods of stagnation followed by three periods of limited glacial advance during the Holocene. (C) 2000 Elsevier Science Ltd and INQUA. All rights reserved.
\end{abstract}

\section{Introduction}

Nanga Parbat is a relatively isolated massif at the western end of the Great Himalaya (Fig. 1). It comprises a series of high peaks ( $>8000 \mathrm{~m}$ ) that are bounded by the Main Mantle Thrust. Although it has attracted much attention from structural geologists, relatively little work has been undertaken on the glacial geology. The valleys radiating from the Nanga Parbat Massif contain extensive accumulations of Quaternary glaciogenic sediments. Previous glacial geologic work has concentrated on the Rakhiot valley (Sloan et al., 1998) and the middle Indus valley, north of the Nanga Parbat massif (Owen, 1988, 1989; Shroder et al., 1989, 1993; Richards et al., 2000a,b). Research into the genesis of thick sedimentary deposits in other northwest Himalayan regions such as Swat Kohistan (Porter, 1970), the Hunza valley (Derbyshire et al., 1984), the Gilgit-middle Indus region (Owen, 1988; Shroder et al., 1989), Kashmir (Holmes, 1988) and Lahul (Owen et al., 1996, 1997; Sharma and Owen, 1996) has attributed these sediments to a series of Quaternary glacial fluctuations. This research has led

* Corresponding author. Tel.: 909-787-3434; fax: 909-787-4324.

E-mail address: Lewis.owen@ucr.edu (L.A. Owen). to the development of various stratigraphical frameworks for the Himalaya, as summarized in Fig. 1. Although these stratigraphical models do not correlate in detail, they present a broad picture of Quaternary history, involving major ice advances throughout the Pleistocene, with progressively smaller advances towards the present. This paper summarizes the field evidence for Quaternary glaciations around Nanga Parbat. It provides a framework for the chronology of glaciation in this region, but one that needs to be rigorously constrained using absolute dating techniques.

\section{Methods}

Four valleys, the middle Astor, the Rupal, the Rakhiot and the Rama, were chosen for detailed study (Fig. 2). Finsterwalder's 1:50,000 scale topographic map was used as a base for geomorphic mapping, and glacial landforms and sediments were mapped using the standard techniques of Derbyshire et al. (1984) and Owen (1988, 1991). Using the methods of Owen (1994), great care was taken in distinguishing between glacial and non-glacial diamicts in this region because of the widespread mass movement and rapid resedimentation of deposits. Standard sedimentary logging techniques were 

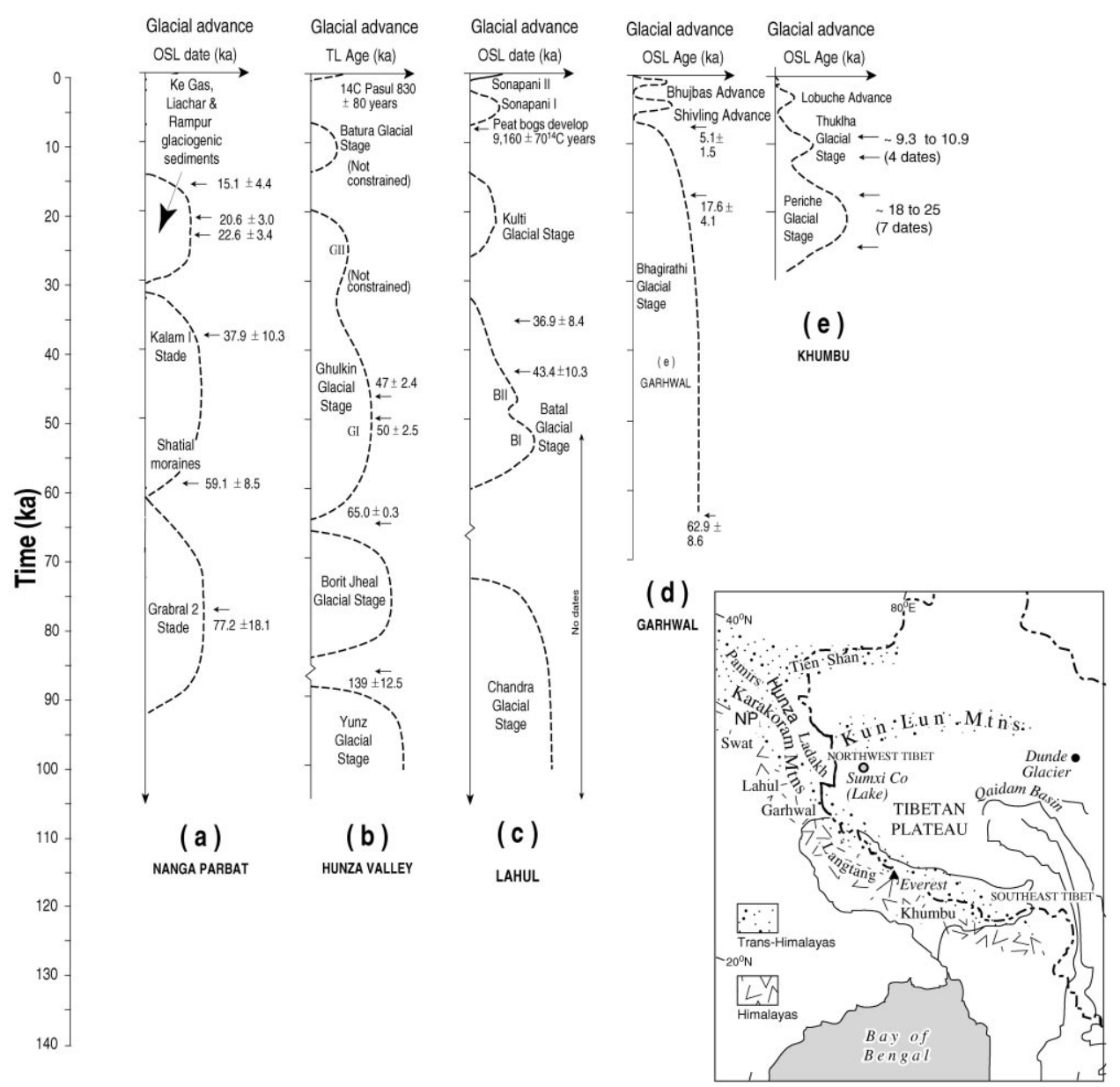

Fig. 1. Relative chronologies and dates for glaciations in Northern Pakistan. (a) OSL dates and relative chronologies for Northern Pakistan after Richards et al. (2000a), (b) Hunza valley after Derbyshire et al. (1984), (c) Lahul Himalaya after Owen et al. (1997), (d) Garhwal Himalaya after Sharma and Owen (1996) and (e) Khumbu Himal after Richards et al. (2000b) (NP = Nanga Parbat).

used (Tucker, 1982; Eyles et al., 1983) on sections where direct measurement was possible. On many faces where direct measurement was rendered impossible by land ownership constraints, or extremely difficult terrain, photogrammetric techniques were used to determine vertical distances, supplemented by field sketches. Care was taken in the construction of sedimentary logs to include any lateral variation along with vertical variation. This allowed the facies to be interpreted using the methods described by Eyles et al. (1983) and Shaw (1986). Sediments consisting of grains coarser than $5 \mathrm{~mm}$ in diameter were classified in the field on the basis of particle size (Wentworth, 1922). Particle shape was estimated using Zingg's (1935) and Powers' (1953) visual comparison charts. Particle size distributions were determined in the laboratory on selected samples by a combination of wet and dry sieving (British Standards Institute, 1975). Orientated blocks of sediment were prepared and their microfabrics were studied in the scanning electron microscope (SEM) using the methods of McGown and Derbyshire (1977).
Relative dating was used to arrive at a temporal subdivision of the sedimentary units, based on the premise that rock weathering, soil development and biological growth are time dependent. Where effects of non-temporal factors such as altitude are minimized, any differences in relative dating can be used as a reflection of age. The techniques used in this study follow those used by Porter (1970) in Swat Kohistan, the International Karakoram Project (Derbyshire et al., 1984) in the Hunza valley, Holmes (1988) in Kashmir, and Shiraiwa and Watanabe (1991) in the Langtang Valley, Nepal. This study used a multi-parameter approach which increases the quantity and the quality of the data and strengthens the conclusions.

Morphostratigraphy and the principle of superposition (Porter, 1970; Derbyshire et al., 1984; Owen, 1988; Shiraiwa and Watanabe, 1991) were used to distinguish between sedimentary units and to form an outline chronology. Rock varnish was used as an indicator of the relative age of a particular surface using the index developed by Derbyshire et al. (1984). Clast weathering was used successfully by Shiraiwa and Watanabe (1991) to 


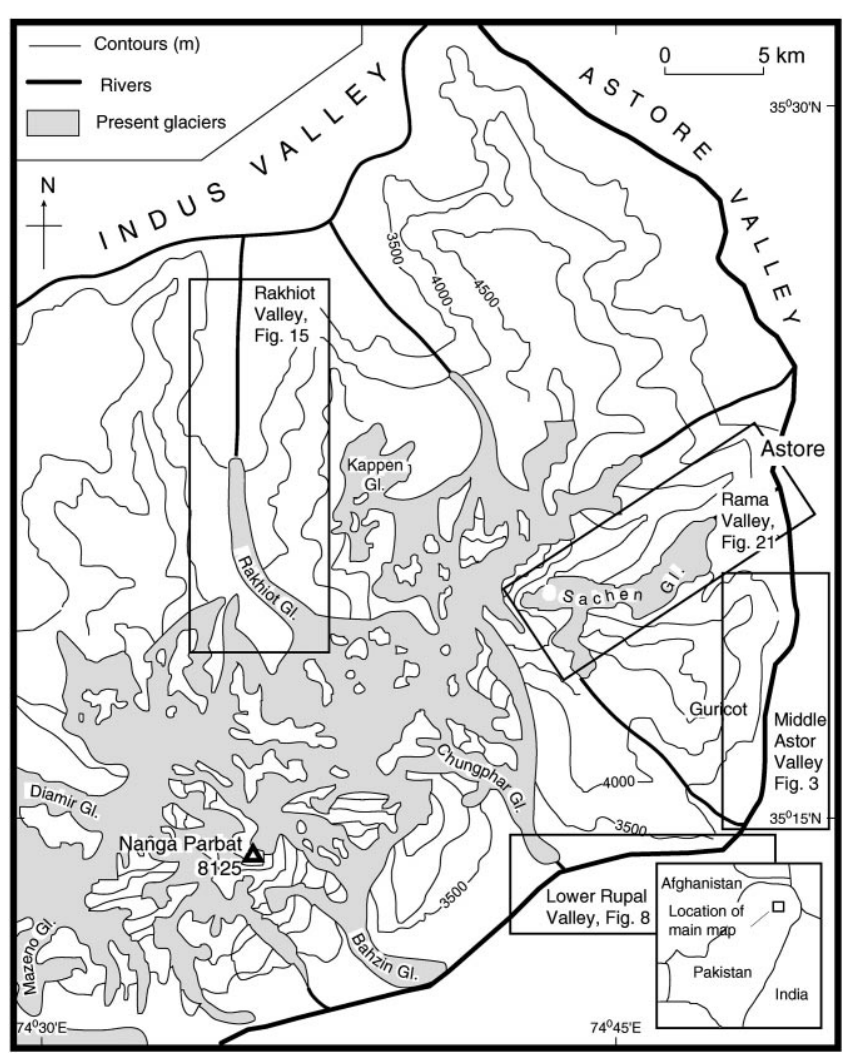

Fig. 2. Location of the detailed study areas in the Nanga Parbat massif.

distinguish between sedimentary units of different ages. Using their criteria, weathering ratios in the form of the number of unweathered: jointed: disintegrated clasts were obtained by measuring 50 clast samples at the rock varnish sampling sites in the Rakhiot and Lower Rupal Valleys. A second value of clast weathering within sedimentary units was obtained by measuring the percentage of clasts which are flaked and split and those which are pitted. Although found to be an unsatisfactory technique by Porter (1970) in Swat Kohistan, such measurements were used successfully by Derbyshire et al. (1984) in the Hunza valley. Following the criteria of the latter authors, values for the percentages of flaked and split boulders, and pitted boulders were also obtained from the rock varnish sampling sites in the Rakhiot and Lower Rupal Valleys.

\section{Middle Astor valley}

The geomorphology and sedimentology of the middle Astor valley is shown in Fig. 3. Evidence of glacial erosion and deposition is present at two altitudes on the valley sides (Fig. 3). The highest evidence on the valley sides is a clear break in slope, which can be identified at approximately $300 \mathrm{~m}$ above the valley floor. This feature, although intermittent throughout the valley, forms

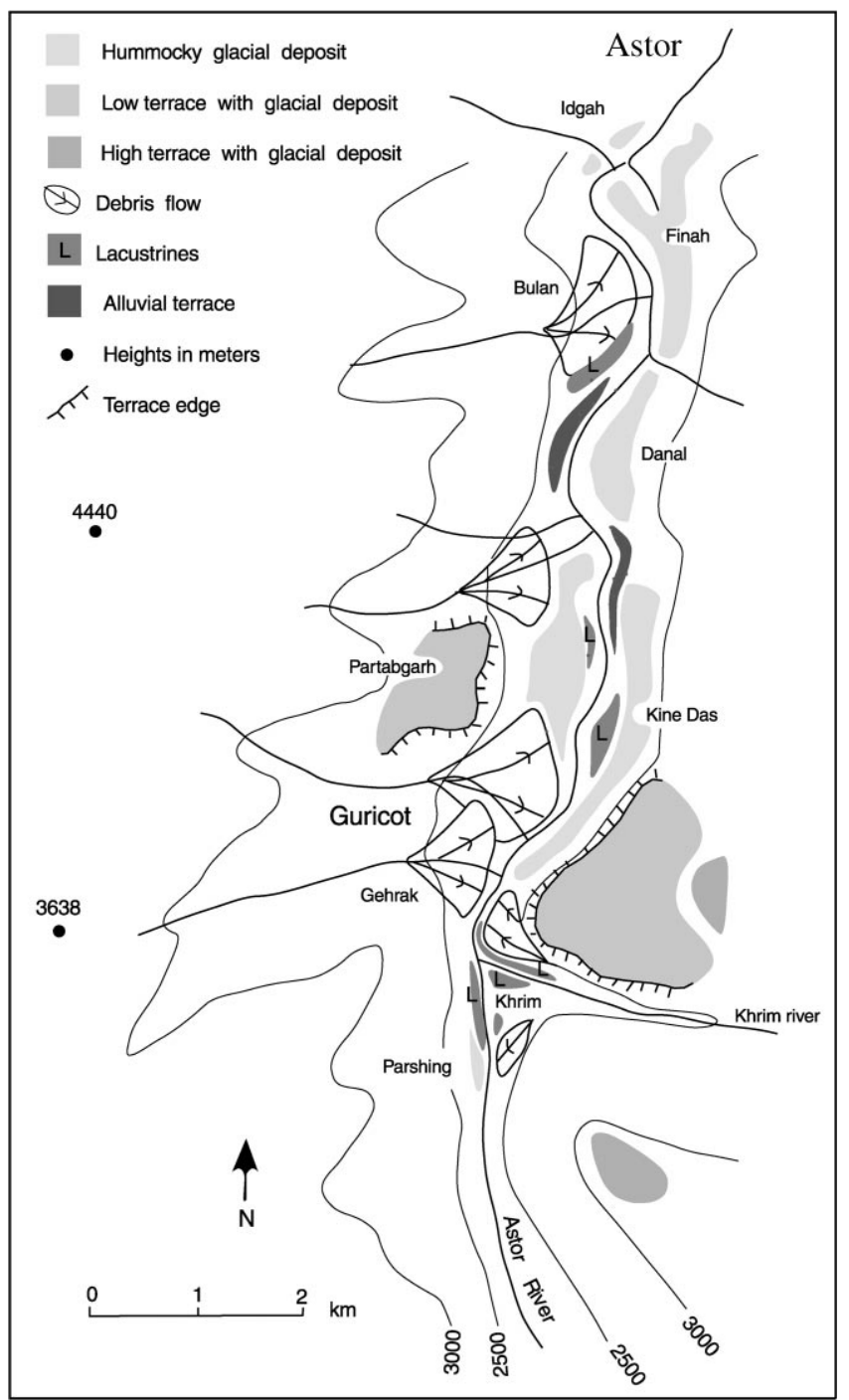

Fig. 3. Geomorphological map of the Astor valley.

a well-defined high-level bench which can be seen above Kine Das (2900 m), Danal (2900 m) and Finah (2600 m) on the east side of the valley and at Astor (2600 m), Idgah $(2800 \mathrm{~m})$, and at Parshing $(2900 \mathrm{~m})$ and Partabgarh $(2700 \mathrm{~m})$ on the west side (Fig. 3). It can be traced as a break in slope down the Astor valley to Harchu, $9 \mathrm{~km}$ north of Astor. At Kine Das, Partabgah and Idgah, compact bouldery diamictons are present on the benches. These poorly sorted deposits appear, on the basis of field observations, to be meltout till. They contain large angular clasts which exhibit edge rounding within a predominantly fine-grained matrix. Particle size analysis of the Kine Das deposit (Fig. 4A) shows that, whilst most of the material is texturally similar, there are localized areas within the massive structure where fine silts and clays have been depleted. SEM analysis shows the microfabric to exhibit irregularly orientated sub-vertical "pseudoshears" (Table 1), which are likely to be the result 


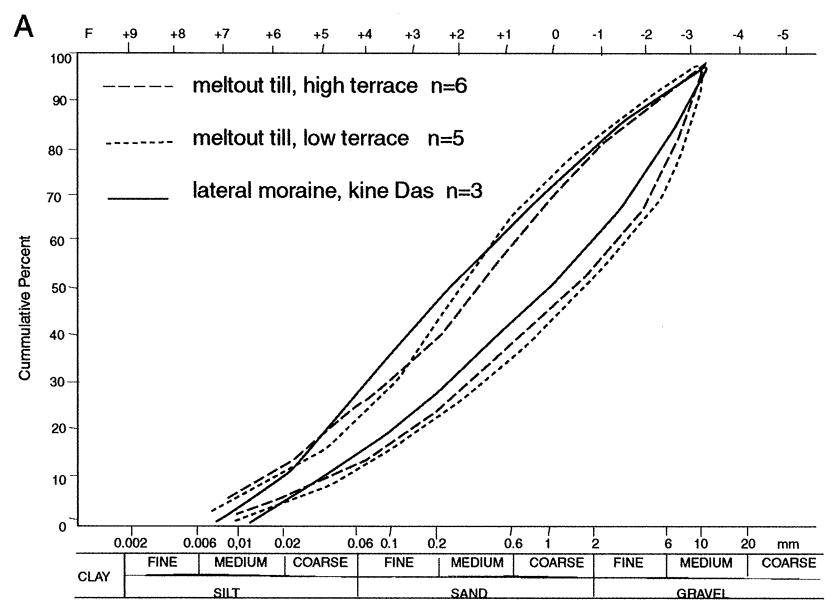

B

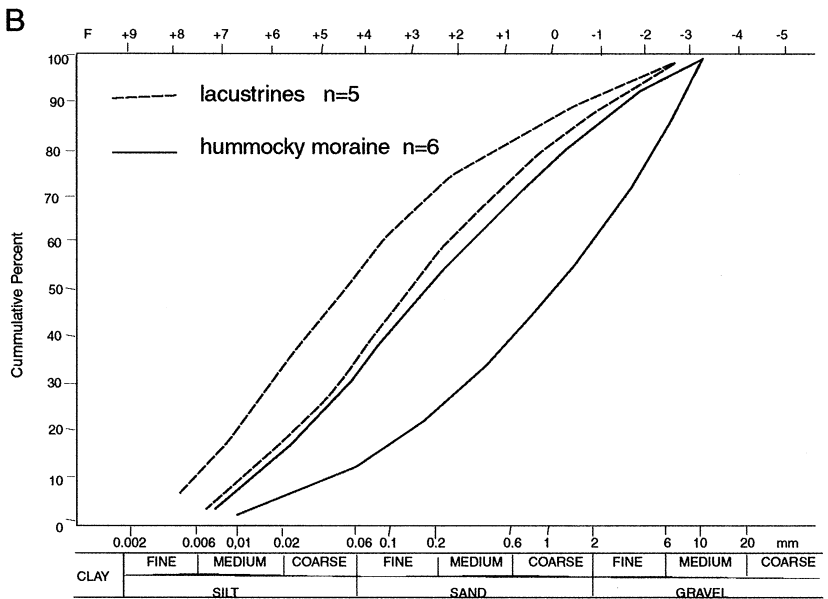

Fig. 4. Particle size distribution envelopes for glacial and lacustrine deposits in the middle Astor valley, (A) valley side deposits and (B) valley floor deposits.

of irregular settling of material (e.g. Owen, 1991). This combination of evidence confirms the initial field identification of the material on these benches as meltout till. The post-maximal rock varnish present on the surfaces of the large boulders within these deposits, following the criteria of Derbyshire et al. (1984), suggests they are of considerable age.

A second series of terrace deposits, $100 \mathrm{~m}$ above the floor of the Astor valley, consist of poorly sorted diamicton (Fig. 3). These can be seen at Danal (2743 m), Finah $(2342 \mathrm{~m})$, Kine Das $(2400 \mathrm{~m})$, Guricot $(2351 \mathrm{~m})$ and Khirim ( $2550 \mathrm{~m}$ ), but cannot be traced beyond Astor. In the field these appear to be tills, containing many large (with long axes of up to $40 \mathrm{~cm}$ ) and medium sized clasts with rounded edges, within a silt-rich to sandy matrix. The presence of some localized and crude sub-horizontal layering within the massive structure of these units suggests they may be of meltout origin. Particle size analysis of the matrix suggests that the material is poorly sorted with localized areas where silt and clay particle sizes are less abundant (Fig. 4). Microfabric analysis under the
SEM reveals the alignment of clays within this till, forming pseudoshears (Table 1), which are documented features of downwasting (Owen, 1991). Again this is in agreement with the identification of these deposits as meltout tills (Owen, 1991).

At Gehrak, a low terrace of glacial sediments forms an inlier within valley side deposits (Fig. 3). These deposits are overlain by colluvial sediments (Fig. 5), the contact between the two materials being sharp. The colluvium consists of poorly sorted massive and stratified diamictons with similar particle size characteristic to meltout tills. The clasts within the colluvial deposits are disposed sub-horizontally and are more angular in shape than those of the underlying meltout till, which is more compact and poorly sorted, and contains clasts with rounded edges. It exhibits no stratification.

A material texturally similar to the tills forming these lower terrace deposits was found at Kine Das (2400 m). It has a well defined ridge morphology and lies approximately $100 \mathrm{~m}$ above the valley floor, and is over $500 \mathrm{~m}$ long. Its fines-rich matrix and large clasts suggest a glacial origin, but its distinctive morphology is not consistent with the meltout process. Particle size analysis of matrix samples showed the material to be texturally uniform, with no significant localized sorting within the deposit. Large exposed boulders within this lateral moraine show advanced surface weathering with post-maximal rock varnish.

The presence of glaciogenic deposits at two distinct levels on the sides of the middle Astor valley suggests two stages of glaciation. For the ice to have extended into the Astor valley, the glacier from the Rupal valley must have advanced considerably. It appears most likely that this was at a time in the Pleistocene when temperatures were sufficiently low to support such a large ice mass at such relatively low altitudes. The weathering state of the surfaces of the large boulders (post-maximal), by analogy with the Hunza valley (Derbyshire et al., 1984), suggests an age perhaps as old as the Middle Pleistocene. The evidence of extensive and intense erosion and reworking of glaciogenic debris from valley side locations to the valley floor is also consistent with such an age estimate.

As well as the valley side deposits, accumulations of diamictons exist as a hummocky, chaotic assemblage of low mounds and depressions across the floor of the middle Astor valley. Their hummocky topography gives the appearance of till produced by local glacial stagnation (Hoppe, 1952; Benn, 1990). In some places these poorly sorted deposits are visible in sections resulting from dissection by the Astor River.

In these sections, the identification of boulder beds (formed by the depletion of fine matrix), small scale and localized stratification of deposits, depletion of fines and also accumulation of fines suggest that this material is a meltout till. The deposits are generally massive with a sandy matrix (Fig. 4B), but with many localized areas of 
Table 1

Microfabric for glacial and non-glacial diamicton in Nanga Parbat study areas

\begin{tabular}{|c|c|c|c|c|c|}
\hline Sample location & Shearing & Stratification & Packing & Fabric & Grain features \\
\hline $\begin{array}{l}\text { Kine Das high } \\
\text { terrace meltout till }\end{array}$ & $\begin{array}{l}\text { Pseudoshears - } \\
\text { irregular orientation }\end{array}$ & None & $\begin{array}{l}\text { Open, localized } \\
\text { compact zones }\end{array}$ & Diffuse & \\
\hline $\begin{array}{l}\text { Kine Das low } \\
\text { terrace meltout till }\end{array}$ & $\begin{array}{l}\text { Pseudoshears - } \\
\text { irregular orientation }\end{array}$ & $\begin{array}{l}\text { Localized micro- } \\
\text { lamines of sift }\end{array}$ & $\begin{array}{l}\text { Open, localized } \\
\text { compact zones }\end{array}$ & Diffuse & \\
\hline Gehrak till & Localized pseudoshears & None & $\begin{array}{l}\text { Open, localized } \\
\text { compact zones }\end{array}$ & Diffuse & \\
\hline $\begin{array}{l}\text { Gehrak debris } \\
\text { flow }\end{array}$ & $\begin{array}{l}\text { Widespread- } \\
\text { downslope dip }\end{array}$ & $\begin{array}{l}\text { Present in parallel } \\
\text { to debris surface }\end{array}$ & Open and porous & Diffuse & \\
\hline $\begin{array}{l}\text { Astor valley } \\
\text { hummocky till }\end{array}$ & $\begin{array}{l}\text { Many irregular } \\
\text { pseudoshears }\end{array}$ & $\begin{array}{l}\text { Localized micro- } \\
\text { lamines of sift }\end{array}$ & $\begin{array}{l}\text { Open, localized } \\
\text { compact zones }\end{array}$ & $\begin{array}{l}\text { Diffuse some vertically } \\
\text { disposed silts }\end{array}$ & \\
\hline $\begin{array}{l}\text { Rampur basal } \\
\text { till }\end{array}$ & $\begin{array}{l}\text { Widespread with } \\
\text { up-valley dip }\end{array}$ & $\begin{array}{l}\text { Pseudolaminae- } \\
\text { aligned with shears }\end{array}$ & $\begin{array}{l}\text { Overconsolidated, } \\
\text { localized open zones }\end{array}$ & $\begin{array}{l}\text { High grain } \\
\text { anisotrophy }\end{array}$ & $\begin{array}{l}\text { Localised } \\
\text { bridges of } \\
\text { cemented grains }\end{array}$ \\
\hline Churit basal till & $\begin{array}{l}\text { Widespread with } \\
\text { up-valley dip }\end{array}$ & $\begin{array}{l}\text { Pseudolaminae- } \\
\text { aligned with shears }\end{array}$ & $\begin{array}{l}\text { Overconsolidated, } \\
\text { localized open zones }\end{array}$ & $\begin{array}{l}\text { High grain } \\
\text { anisotrophy }\end{array}$ & $\begin{array}{l}\text { Edge crushing } \\
\text { of grains }\end{array}$ \\
\hline $\begin{array}{l}\text { Churit meltout } \\
\text { till }\end{array}$ & $\begin{array}{l}\text { Pseudoshears - irregular } \\
\text { orientation, subvertical }\end{array}$ & None & $\begin{array}{l}\text { Open, localized } \\
\text { compact zones }\end{array}$ & Diffuse & $\begin{array}{l}\text { Edge crushing } \\
\text { of grains }\end{array}$ \\
\hline $\begin{array}{l}\text { Tarshing meltout } \\
\text { till }\end{array}$ & $\begin{array}{l}\text { Pseudoshears - irregular } \\
\text { orientation and dip }\end{array}$ & $\begin{array}{l}\text { Microlaminae, } \\
\text { some deformed }\end{array}$ & $\begin{array}{l}\text { Open, localized } \\
\text { compact zones }\end{array}$ & Diffuse & \\
\hline $\begin{array}{l}\text { Tato high terrace } \\
\text { meltout till }\end{array}$ & $\begin{array}{l}\text { Pseudoshears - irregular } \\
\text { orientation and dip }\end{array}$ & $\begin{array}{l}\text { Microlaminae, } \\
\text { some deformed }\end{array}$ & $\begin{array}{l}\text { Open, localized } \\
\text { compact zones }\end{array}$ & Diffuse & $\begin{array}{l}\text { Localised } \\
\text { bridges of } \\
\text { cemented } \\
\text { grains }\end{array}$ \\
\hline $\begin{array}{l}\text { Tato hummocky } \\
\text { till }\end{array}$ & $\begin{array}{l}\text { Pseudoshears - subvertical } \\
\text { and irregular orientation }\end{array}$ & $\begin{array}{l}\text { Microlaminae, } \\
\text { some deformed }\end{array}$ & $\begin{array}{l}\text { Open, localized } \\
\text { compact zones }\end{array}$ & $\begin{array}{l}\text { Diffuse, some vertically } \\
\text { disposed silts }\end{array}$ & \\
\hline $\begin{array}{l}\text { Fugtoury meltout } \\
\text { till }\end{array}$ & $\begin{array}{l}\text { Irregular pseudoshears } \\
\& \text { some down-valley } \\
\text { shear structures }\end{array}$ & $\begin{array}{l}\text { Microlaminae } \\
\text { of silt }\end{array}$ & $\begin{array}{l}\text { Open, localized } \\
\text { compact zones }\end{array}$ & $\begin{array}{l}\text { Diffuse, some vertically } \\
\text { disposed silts }\end{array}$ & $\begin{array}{l}\text { Localised } \\
\text { bridges of } \\
\text { cemented grains }\end{array}$ \\
\hline Astor meltout till & $\begin{array}{l}\text { Irregular pseudoshears } \\
\& \text { some down-valley } \\
\text { shear structures }\end{array}$ & $\begin{array}{l}\text { Microlaminae } \\
\text { of silt, } \\
\text { some deformed }\end{array}$ & $\begin{array}{l}\text { Open, localized } \\
\text { compact zones }\end{array}$ & Diffuse & \\
\hline $\begin{array}{l}\text { Rama terrace } 1 \\
\text { meltout till }\end{array}$ & $\begin{array}{l}\text { Pseudoshears - subvertical } \\
\text { and irregular orientation }\end{array}$ & $\begin{array}{l}\text { Microlaminae, } \\
\text { some deformed }\end{array}$ & $\begin{array}{l}\text { Open, localized } \\
\text { compact zones }\end{array}$ & $\begin{array}{l}\text { Diffuse, some vertically } \\
\text { disposed silts }\end{array}$ & \\
\hline $\begin{array}{l}\text { Rama terrace } 2 \\
\text { meltout till }\end{array}$ & $\begin{array}{l}\text { Pseudoshears - subvertical } \\
\text { and irregular orientation }\end{array}$ & $\begin{array}{l}\text { Microlaminae, } \\
\text { some deformed }\end{array}$ & $\begin{array}{l}\text { Open, localized } \\
\text { compact zones }\end{array}$ & $\begin{array}{l}\text { Diffuse, some vertically } \\
\text { disposed silts }\end{array}$ & \\
\hline
\end{tabular}

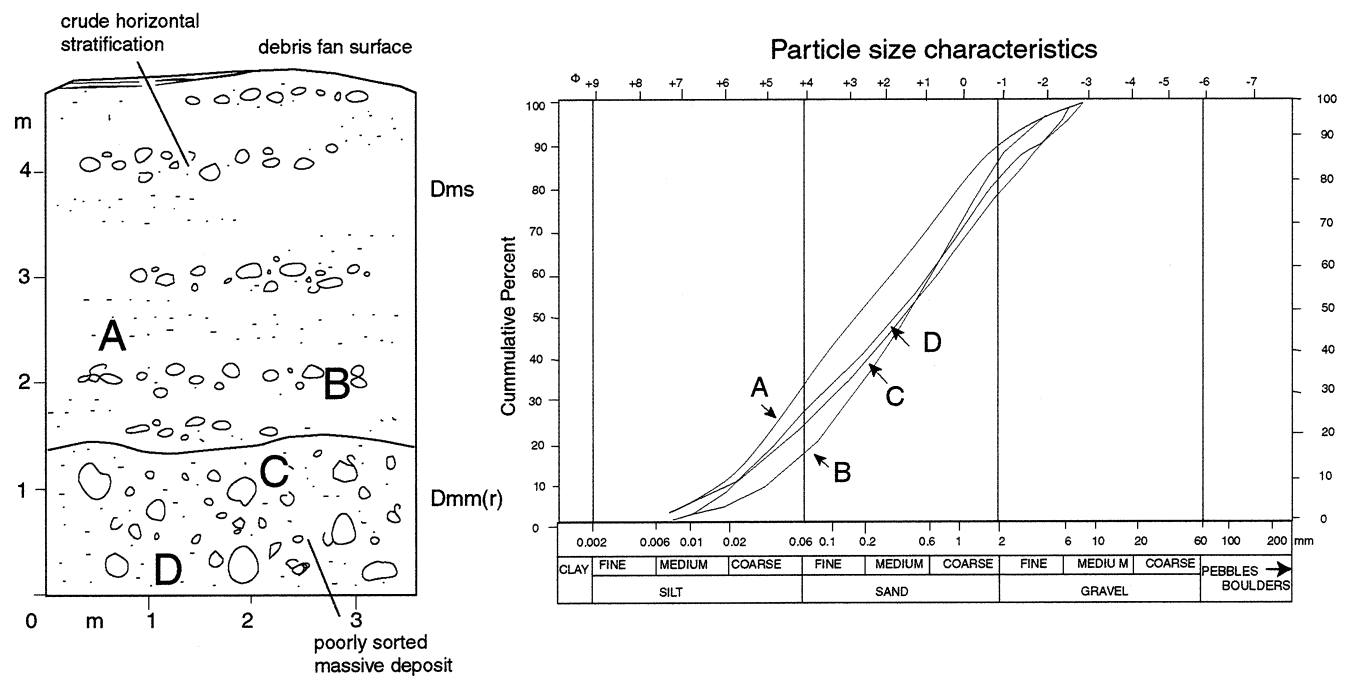

Fig. 5. Section through a debris fan at Gehrak in the middle Astor valley showing a glacial deposit at its base and particle size results for samples A-D. The locations of samples A-D are shown on the section. Lithofacies codes after Eyles et al. (1983). 


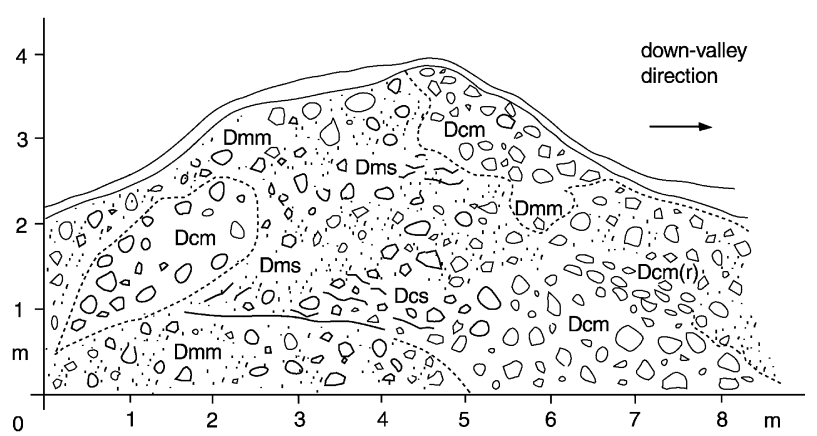

Fig. 6. Section through a hummock on the floor of the middle Astor valley. Lithofacies codes after Eyles et al. (1983) (Dmm — massive matrix-supported diamicton; Dms - stratified matrix-supported diamicton; Dcm - massive clast-supported diamicton; Dcs - stratified clast-supported diamicton).

fines depletion or accumulation, as shown in Fig. 6. At the microscopic scale, the fabric appears to be diffuse with large numbers of pseudoshears having many different orientations and dips (Table 1). This evidence supports the initial identification of the material as a meltout till (Owen, 1991), but suggests that it has been subjected to widespread resedimentation during deposition because of the highly localized internal stratification and sorting within an otherwise massive diamicton (Haldorsen and Shaw, 1982). These hummocky tills are thus considered to be the product of ice wastage during the final glacial retreat up the Astor valley.

Following the retreat of the ice, non-glacial geomorphological processes reworked and resedimented many of the glacial deposits, incorporating them within debris fans and other slope deposits, and in some places almost completely removing them. Evidence for resedimentation and redeposition from the valley side benches down to the valley floor in the form of debris flows and slides is widespread, some benches being surrounded by a drape of redeposited material (e.g. at Astor). The redeposited material is similar to the deposits found on the benches in respect of particle size, clast lithology and degree of clast weathering and edge rounding. However, its directional fabric exhibits a marked difference, as it has a welldeveloped mean dip towards the valley floor, and a mean orientation at right angles to the main valley in which it was redeposited.

\section{Rupal valley}

The Rupal valley runs along the south side of the massif (Figs. 2 and 7). There are several glaciers in its tributary valleys to the north, and the Rupal glacier lies at its head, some $24 \mathrm{~km}$ up-valley. Large accumulations of both glacial and non-glacial sediments have been exposed by downcutting of the Rupal River. Four morphostratigraphic units have been recognised in the form of terraces $\mathrm{Tl}$ to $\mathrm{T} 4$, and at least four distinct sedimentary units can be identified. Fig. 8 summarizes the evidence for these morphostratigraphic and sedimentary units, observed along sections from Tarshing to the easternmost end of the valley. Each terrace will be described in turn.

\subsection{Rampur terrace (T1)}

At the base of the terrace at Rampur, 2 to $6 \mathrm{~m}$ above the present river level, an overconsolidated and poorly

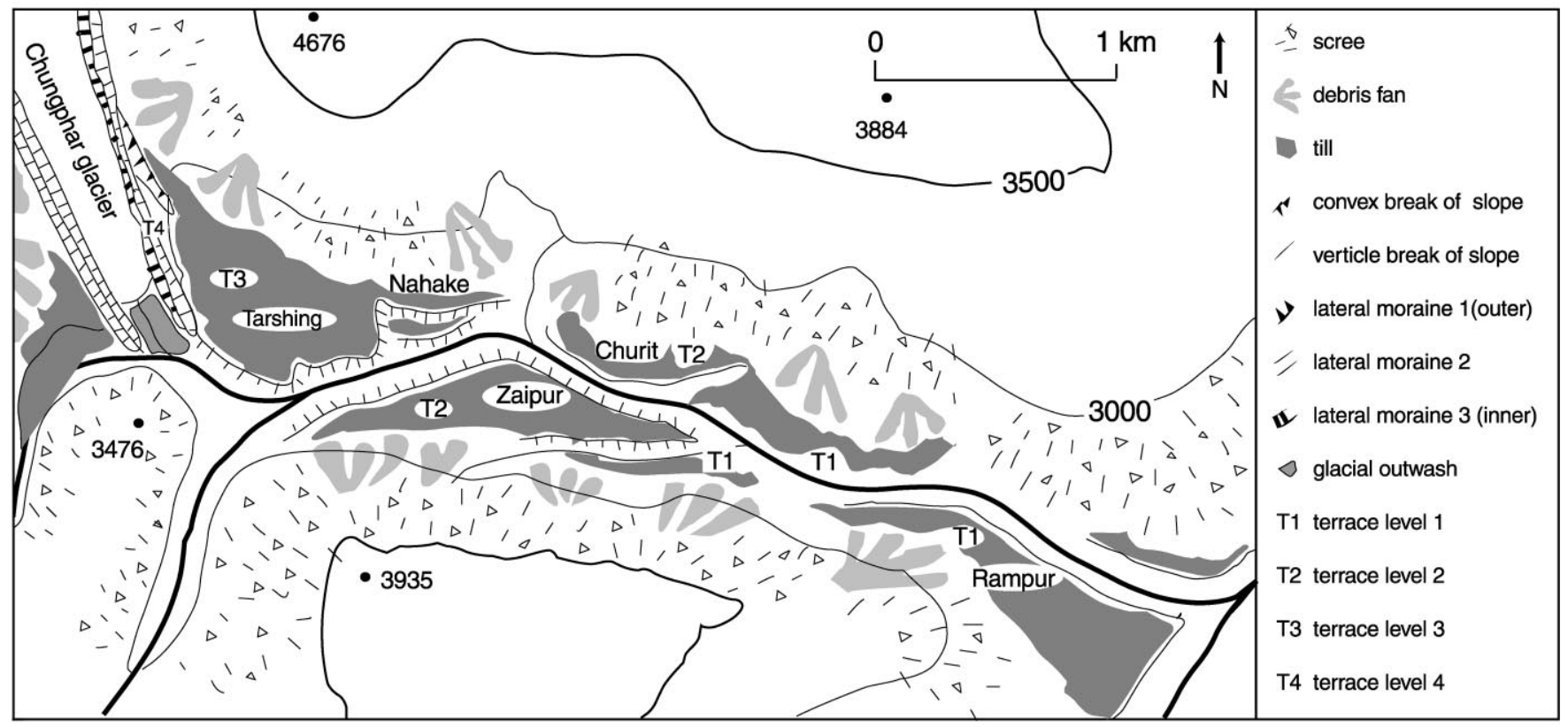

Fig. 7. Geomorphological map of the Rupal valley. 

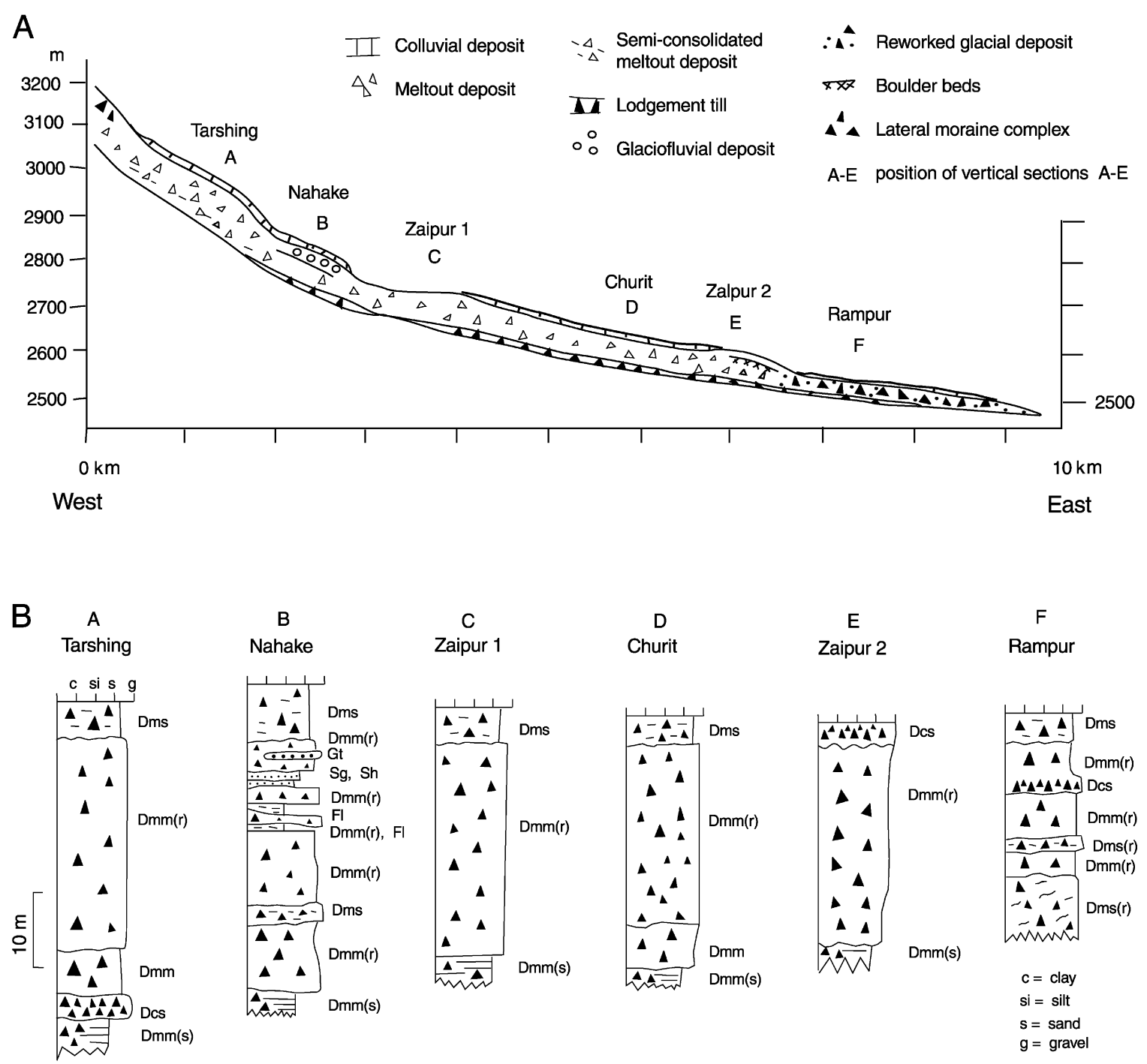

Fig. 8. (A) Longitudinal profile and deposits of the Rupal valley between Tarshing and Rampur, (B) vertical sedimentary profiles through diamicton deposits in the Rupal valley. Lithofacies codes after Eyles et al. (1983) (Dmm - massive matrix-supported diamicton; Dms - stratified matrixsupported diamicton; Dcm - massive clast-supported diamicton; Dcs — stratified clast-supported diamicton; Fl — silts with fine lamination often with minor fine sand and very small ripples; $\mathrm{Sg}$ — sand with graded bedding; Sh — sand with horizontal planar bedding; Gt — gravels with trough cross-bedding; (r) - evidence of resedimentation; (s) - sheared).

sorted material of uncertain thickness is present (Fig. 8). It contains a high proportion of sub-rounded clasts and appears to have a much finer matrix than any other deposits exposed in the sediment series. Localized shearing can be observed. On the basis of these textural characteristics, the rounded shape of its clasts and its position at the base of the sediment series, this material was classified in the field as a basal deformation till. SEM observation revealed shearing of the tightly packed matrix and edge crushing of single particles (Table 1) also consistent with a subglacial origin (Owen, 1991). Particle size analysis showed it to be far finer than any of the other samples collected from this valley (Fig. 9), the high silt content being characteristic of deformation and/or lodgement till. This deformation till was probably laid down during a period when the Rupal glacier was more extensive than at present.

Above the deformation till, massive units of poorly sorted diamicton are present down the length of the Rampur terrace, varying in thickness between 35 and $70 \mathrm{~m}$ (Fig. 8). These were interpreted in the field as tills associated with ice wastage up-valley, an interpretation based on the presence of some edge-rounding of the large subangular clasts and the fines-rich matrix supporting these clasts. At the lower end of the valley, localized boulder beds exhibiting crude and sub-horizontal bedding are widespread within the glacial diamicton and, to a lesser extent, localized sand bodies are also present. The sand bodies can be seen in the upper 10 to $20 \mathrm{~m}$ of the vertical profile of the Rampur deposits shown in Fig. 8B. 


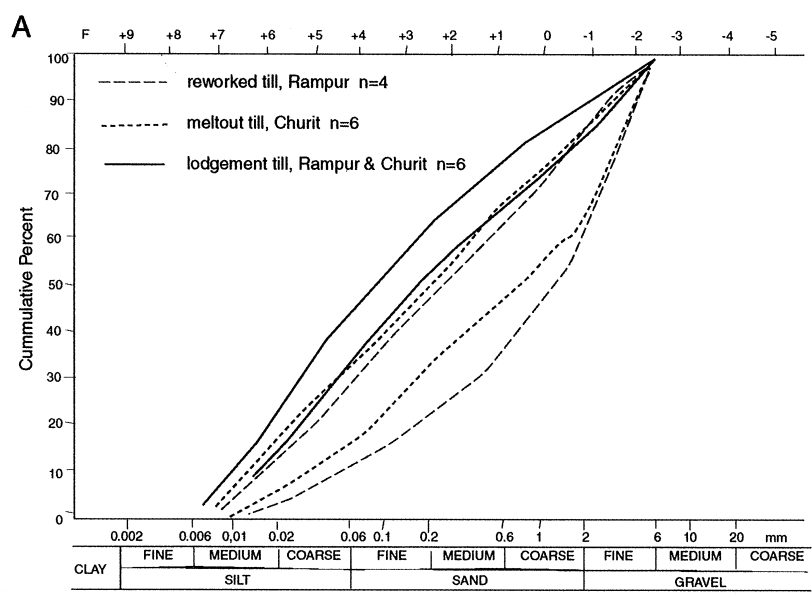

B

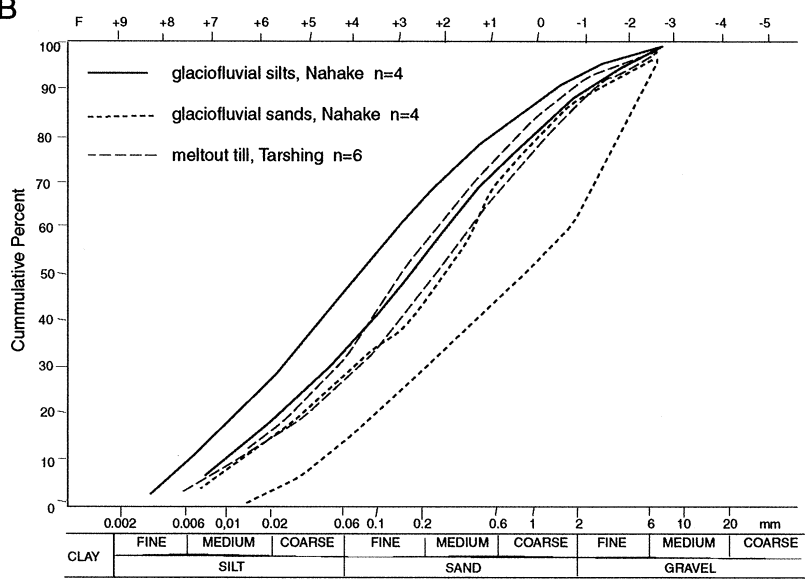

Fig. 9. Particle size distribution envelopes for glacial deposits in the Rupal valley.

Sorting of material was interpreted in the field as evidence of large scale reworking of the till, following ice wastage. Samples of matrix were collected from the tills for particle size and microfabric analysis. The results of the particle size analysis (Fig. 9) show the reworked tills to be coarse and generally depleted of fines, with considerable grain size variability. The clasts within the boulder beds show the best developed fabrics. This combination of characteristics suggests fluvial reworking.

The top 5 to $10 \mathrm{~m}$ of the valley sections at the lower end of the Rampur terrace, as shown at the top of the Rampur vertical profile in Fig. 8B, contain colluvial deposits derived from the valley sides. These are poorly sorted diamictons with a fine-grained matrix. They can be distinguished from the glacially derived materials, however, on the basis of their distinct surface morphology. This consists of debris fans and flows from the valley sides, the contained clasts being angular and subangular, and their directional properties being consistent (Owen and Derbyshire, 1989). Debris flows in this region have well defined leveed channels at the surface and a clearly bedded internal structure, with dips parallel to the depositional slope (Owen, 1988). Clasts within the

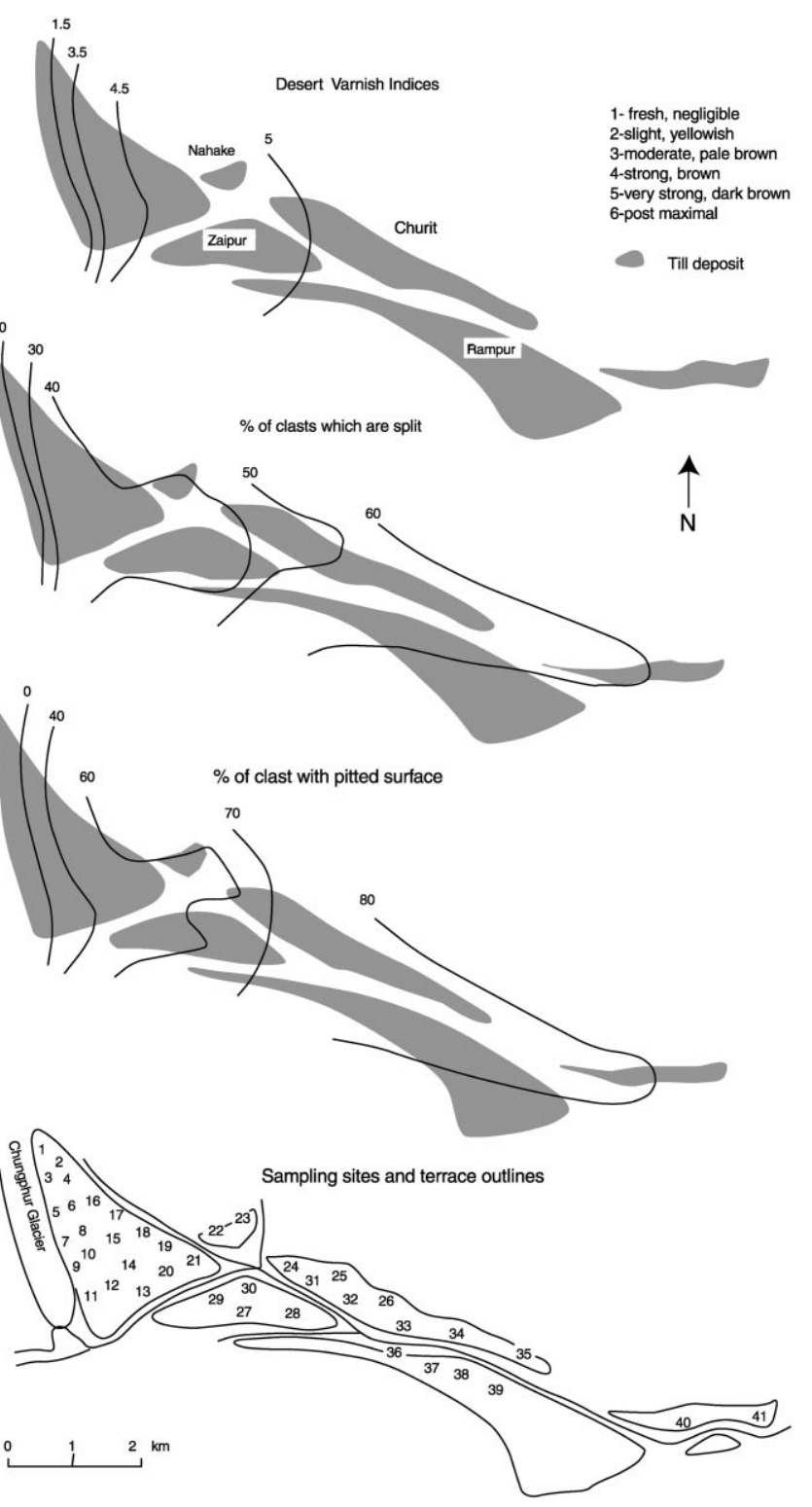

Fig. 10. Relative dating of terraces and moraines along the Rupal valley between Tarshing and Rampur.

debris flows tend to be more angular than glacially derived clasts, with little evidence of edge rounding. These distinctions become less valid where debris flows and other slope processes incorporate glacially derived materials, but, in most cases, they served to discriminate the glacial from the non-glacial diamictons.

Relative dating of the clasts on the surface of these reworked tills using the rock varnish index method, as well as percentages of split and pitted clasts, indicates that they are more weathered, and so may be older than any tills further up the valley (Fig. 10). The similarity in clast weathering values for the tills below Churit and Rampur suggest that they are of similar age, and that the stagnation period resulting in their deposition was broadly synchronous. 


\subsection{Churit and Zaipur terraces (T2)}

These terraces comprise the most extensive valley-fill unit in the Rupal valley, stretching for $1.3 \mathrm{~km}$ downvalley and having thicknesses of between 50 and $100 \mathrm{~m}$ (Fig. 8A). In the field this unit was classified as a predominantly glacial diamicton, with colluvial deposits at its surface, as shown in the vertical profiles $C$ and $D$ in Fig. 8B. At its base is an overconsolidated and poorly sorted material, containing sub-rounded clasts in a finesrich matrix (less extensive but similar to that identified as a deformation till in the Rampur unit). Localized evidence of shearing within this diamicton is shown at the base of the vertical profile D in Fig. 8B. On the basis of its field characteristics, this material is also classified as a basal deformation till. Its particle size is texturally similar to the basal tills at Rampur (Fig. 9), and the high silt content is characteristic of a basal till (Boulton, 1978). The microfabric of this deposit has a tightly packed and overconsolidated matrix, with some localized dilation joints (Table 1), both being recognized features of lodgement tills (Owen, 1991). These results support a subglacial origin for this till. It is suggested that it is a product of the same glacial advance that produced the basal deposits at Rampur.

A massive and poorly sorted glacial diamicton between 50 and $90 \mathrm{~m}$ thick is present above the previously described sediment (profiles $\mathrm{C}$ and $\mathrm{D}$ in Fig. 8B). It contains large angular clasts in a fines-rich matrix, the clasts showing signs of edge rounding. Sorting of material appears to be highly localized with some small boulder beds and pockets of fines-rich sediments revealed in the sections. Particle size analysis of samples of the matrix confirms its uniformly massive nature. Observation of the microfabric using the SEM provides results in accord with this, with many irregular "pseudoshears" and deformed laminations being present (Table 1), indicating irregular settling of material (Owen, 1991).

At the lower (eastern) end of both the Churit and Zaipur terraces, the surface drops steeply down to the Rampur terrace, as shown by the vertical and convex breaks in slope in Fig. 7. At the downstream end of the Zaipur terrace this decline in surface elevation is steplike. Down-valley of these steps, the end of the Zaipur unit contains a stratified bouldery diamicton exposed within the uppermost 5 to $10 \mathrm{~m}$ of the meltout till (profile $\mathrm{E}$ in Fig. 8B). These boulders are found more than $1 \mathrm{~km}$ downstream of the Zaipur unit. These deposits evidence of bedding and the fine matrix has been depleted (Fig. $8 \mathrm{~B}$ ), evidence consistent with fluvial activity across the surface of the meltout deposits immediately below Churit. Together with the large increase in terrace height across the valley at Churit and Zaipur, this suggests that a still-stand took place near to Churit and Zaipur during glacier retreat.
Colluvial deposits, 5-8 $\mathrm{m}$ thick, derived from the valley sides, occur at the top of the Churit and Zaipur terraces, as shown at the top of vertical profiles C and D in Fig. 8B. These were distinguished in the field on the basis of the angularity of the contained clasts, and obvious bedding with dips parallel to the depositional slope (e.g. de Jong and Rappol, 1983; Owen and Derbyshire, 1989).

Relative dating of the clasts on the surface of the meltout tills shows that the Churit and Zaipur tills have similar degrees of surface weathering. However, the clasts lower down the valley are slightly more weathered that those towards the head of the valley. This slight downvalley increase in relative weathering in the tills can be seen in Fig. 10. The similarity of the weathering values within the Churit and Zaipur tills suggests that the episode of stagnation during which these deposits formed was one of extensive, general down-wasting. Fig. 10 also shows that the clasts of the Churit and Zaipur tills appear to be less weathered than those down-valley at Rampur, but more weathered than those up-valley at Tarshing. These results are in agreement with the interpretation of these deposits as meltout tills lain down during a general glacier retreat.

\subsection{Tarshing terrace (T3)}

This distinct terrace is present above the Churit and Zaipur terraces. It is $0.8 \mathrm{~km}$ in length and up to $110 \mathrm{~m}$ thick (Fig. 7). It appears to have sedimentary characteristics similar to the meltout deposits identified at Churit, being a massive glacial diamicton with a fine matrix containing large angular clasts with sub-rounded edges (Fig. 8B). The particle size distribution envelopes for the matrix samples from Tarshing shown in Fig. 9B are similar to the envelopes for the matrix samples from the Churit meltout till shown in Fig. 9A. Some localized fines-rich deposits and boulder beds are present in the Tarshing deposits. The directional fabric of the boulder beds indicates local resedimentation (cf. Dowdeswell et al., 1985). The microfabric of this material is directionally diffuse (Table 1), which is another characteristic indicative of meltout till (Owen, 1991). Fabric analysis from two well sorted deposits within the main body of the till indicate strong localized orientations and dips, suggesting that these are localized mass movement deposits (Lawson, 1979a, b; Owen, 1991). These results support the field identification of this diamicton as a till formed by meltout and subject to resedimentation by localized mass movement. Relative dating measures applied to the Tarshing unit show that all materials within it are of a similar age, with the clasts having a consistent degree of weathering throughout (Fig. 10). This degree of weathering is less than that seen in the tills down valley, so that the Tarshing unit is probably younger than both the Churit and Rampur units, having been formed by a distinct and more recent period of meltout. 


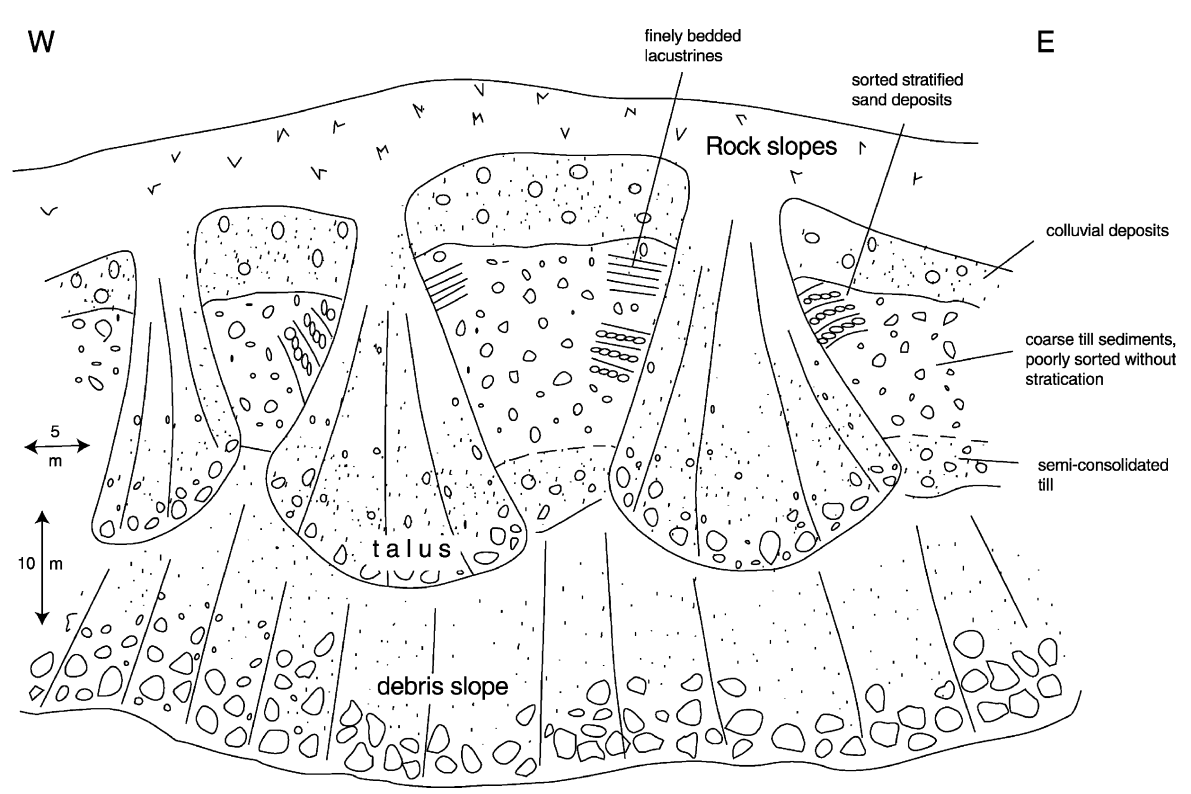

Fig. 11. Vertical exposure through Nahake terrace in the Rupal valley.

Evidence for a second glacial still-stand is also present at Nahake, at the downstream end of the Tarshing terrace. Here, fine lacustrine sediments, stratified sand deposits and channel fills occur, within the top $10 \mathrm{~m}$ of the meltout till (Fig. 11). A vertical profile through these deposits (Fig. 8B) shows the interstratification of these relatively thin (0.5-4 $\mathrm{m}$ thick) deposits at the top of the massive till unit. These well-sorted deposits were classified in the field as glaciofluvial in origin. They indicate considerable glaciofluvial activity in an active proglacial environment, subsequent to the deposition of the subjacent tills. The repeated interstratification of glacial diamicton and waterlain sediments implies sedimentation in an ice-marginal setting (Boulton, 1977) and thus the glacier snout must have been close to Nahake. Some sediment sequences within channel fills are almost $4 \mathrm{~m}$ thick. A period of glacier front stability appears to have occurred close to Nahake and may represent a still-stand during glacier recession, although no evidence of the length of such a still-stand is available.

Active slope processes in the current non-glacial environment have deposited colluvial materials from the valley sides at the top of the Tarshing and Nahake units, as can be seen in the upper part of vertical profiles $A$ and $\mathrm{B}$ in Fig. 8B. These have the distinctive surface morphology and sedimentary characteristics (for example, coarse and variable grain size distributions and angular shaped clasts) indicative of debris flow deposits (de Jong and Rappol, 1983; Owen, 1991).

\subsection{Lateral moraine ridges (T4)}

A series of prominent lateral moraines is present around the present margin of the Chungphar glacier, with distinct ridge forms that appear to be superimposed upon the Tarshing meltout till terrace (Fig. 7). Relative dating of the moraines shows that the clasts on the inner lateral are less weathered, and therefore younger, than those of the outer lateral moraines (Fig. 10). These relative ages are confirmed by the fact that erosion and resedimentation of material on the crests of the outer moraines are greater than those found on the inner. Rock varnish on boulders in these moraines is very poorly developed, suggesting that these deposits are the youngest in the valley. This degree of rock varnish development is comparable to that found on Holocene deposits in the adjacent Karakoram region (Derbyshire et al., 1984) and the age of these moraines may, therefore, be reasonably assigned to the Holocene.

In summary, it is apparent that all of the glacial deposits examined in the Rupal valley were laid down during the wastage and retreat of the Rupal glacier to its present position. Fig. 12 shows a four-phase model for the development of the observed sedimentary sequences. In this model, the retreat of the Rupal glacier up-valley produces the meltout tills which form the Rampur terrace (Stage I). A still-stand in this retreat occurs at Churit to produce a change in surface topography, with meltout tills forming in an ice-contact position at Churit and glacial meltwater reworking the Rampur tills (Stage II). Further glacier retreat to Nahake produces meltout tills which form the Churit and Zaipur terraces, with a subsequent still-stand at Nahake producing glaciofluvial sediments (Stage III). Further glacier retreat, from Nahake, produces meltout tills at Tarshing which form in an ice contact position (Stage IV). The distinct changes in surface morphology down the Rupal valley, along with the glaciofluvial sediment features, suggest two 


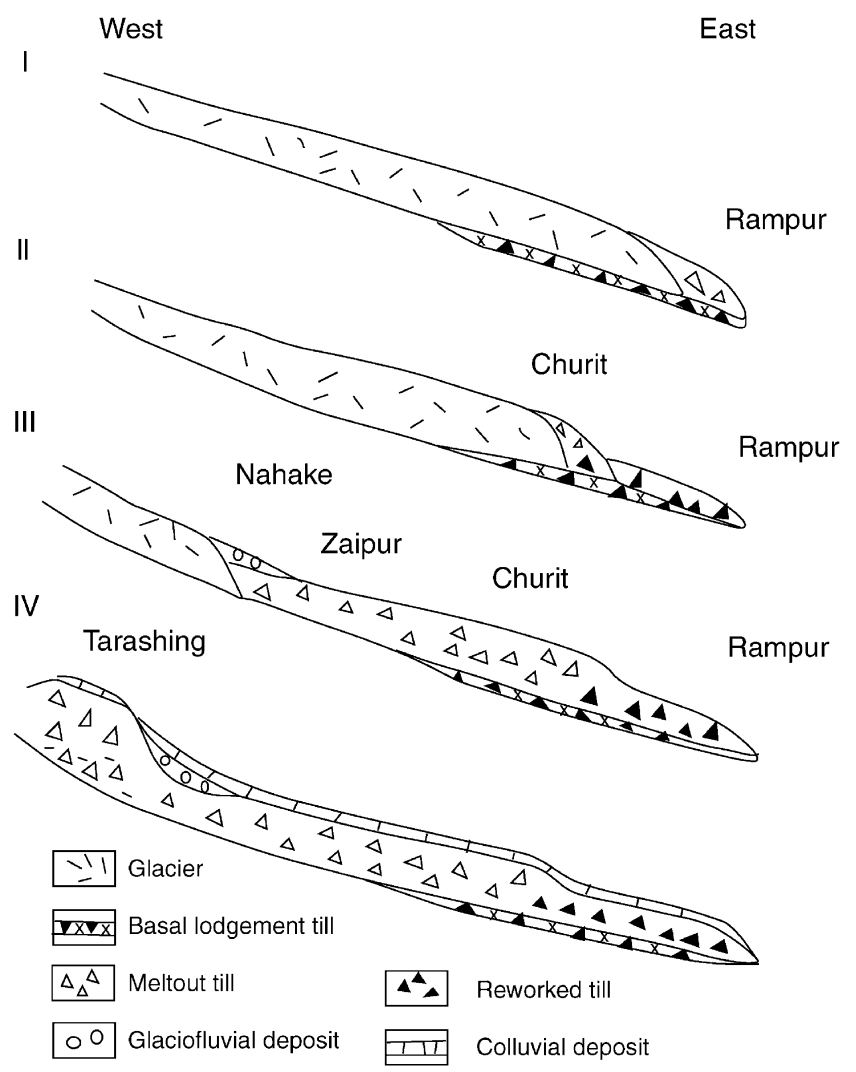

Fig. 12. Schematic development for the deposits in Rupal valley: (I) Glacier retreat up-valley produces meltout tills. (II) Still-stand at Churit, Rampur tills are reworked by glacier meltwater. Meltout tills form in ice-contact position at Churit. (III) Glacier retreat to still-stand at Nahake produces meltout tills along valley. Glaciofluvial sediments accumulate at Nahake. (IV) Glacier retreat forms meltout till at Tarshing. Colluvial diamictons deposited from valley sides down the length of the valley.

still-stands during glacier retreat, the first being at Churit and the second at Nahake. Available evidence is insufficient to demonstrate whether the stages in sediment accumulation represent still-stands punctuating a general glacial retreat or short-term advances of the glacier. However, the evidence presented, implying synchronous ice wastage within each terrace unit, suggests that a process of ice wastage and retreat punctuated by still-stands is more probable.

\section{Rakhiot valley}

The upper part of the Rakhiot valley has truncated spurs, hanging valleys, steep valley sides and an overdeepened trunk valley indicating that glacier levels at some time in the past must have been at least $650 \mathrm{~m}$ higher than those of the present day. Trimlines of this earlier glaciation cannot be identified easily because the contemporary slope processes have resulted in a widespread covering of scree and slope debris (Fig. 13). The narrow river gorge, with its precipitous slopes beginning $2 \mathrm{~km}$ north of Tato, retains no evidence of either a highlevel surface or of till deposits. However, evidence of large-scale glacial activity in the past occurs in the form of tills, traceable along the valley to a point $1.5 \mathrm{~km}$ north of Tato (Fig. 13). These can be divided into four morphologically distinct units termed $\mathrm{Tl}$ and $\mathrm{T} 2$ at Tato, $\mathrm{T} 3$ at Fugtoury and T4 at Bael.

\subsection{Tato high terrace $(T 1)$}

This accumulation of glacial diamictons, $200 \mathrm{~m}$ above the valley floor, represents the most northerly evidence for glaciation in the Rakhiot valley. The deposits occur as a narrow unit extending over a distance of $2.5 \mathrm{~km}$ (Fig. 13). On the basis of their poor sorting, their large angular clasts with signs of edge rounding and their fine matrix, these deposits were classified in the field as glacial diamictons. They are dissected at their down-valley limit and there is evidence of extensive erosion in the form of earth columns along their exposed faces. Localized boulder beds occur within these massive units. There is some with crude down-valley stratification, with interstratified pockets of fines-depleted gravel. Particle size (Fig. 14) and microfabric analysis revealed that, whilst the majority of this till is massive and poorly sorted, there are localized areas of fine sediment depletion and accumulation (Fig. 14). These characteristics are similar to the icecontact fan deposits of Owen and Derbyshire (1989) in the Karakoram region, the localized sorting being evidence of glaciofluvial activity and the fabric being in accord with sediment deposition by meltout and mass movement processes (Owen, 1991). Thus, this deposit is interpreted as an ice-contact diamicton which must have been deposited at a time when the glacier terminus lay at Tato.

\subsection{Lower Tato unit (T2)}

On the Rakhiot valley floor there are thick hummocky diamictons dissected by the Rakhiot River that have the appearance of a till produced by local glacial stagnation. They are poorly sorted and contain large angular and sub-angular clasts with signs of edge rounding within a fine-grained matrix. There are localized concentrations of large clasts and some fines-rich pockets (observed in the river sections). This is consistent with classification of this deposit as a meltout till (Haldorsen and Shaw, 1982; Derbyshire et al., 1985). Particle size analyses show the deposits to be texturally massive, similar particle size distributions pertaining throughout the unit (Fig. 14). This is probably a meltout till similar to those described by Owen (1991) in the Karakoram Mountains.

The degree of weathering of the surfaces of the large clasts within both these units at Tato indicates similar advanced stages of weathering, with the boulders displaying post-maximal rock varnish and high percentages 


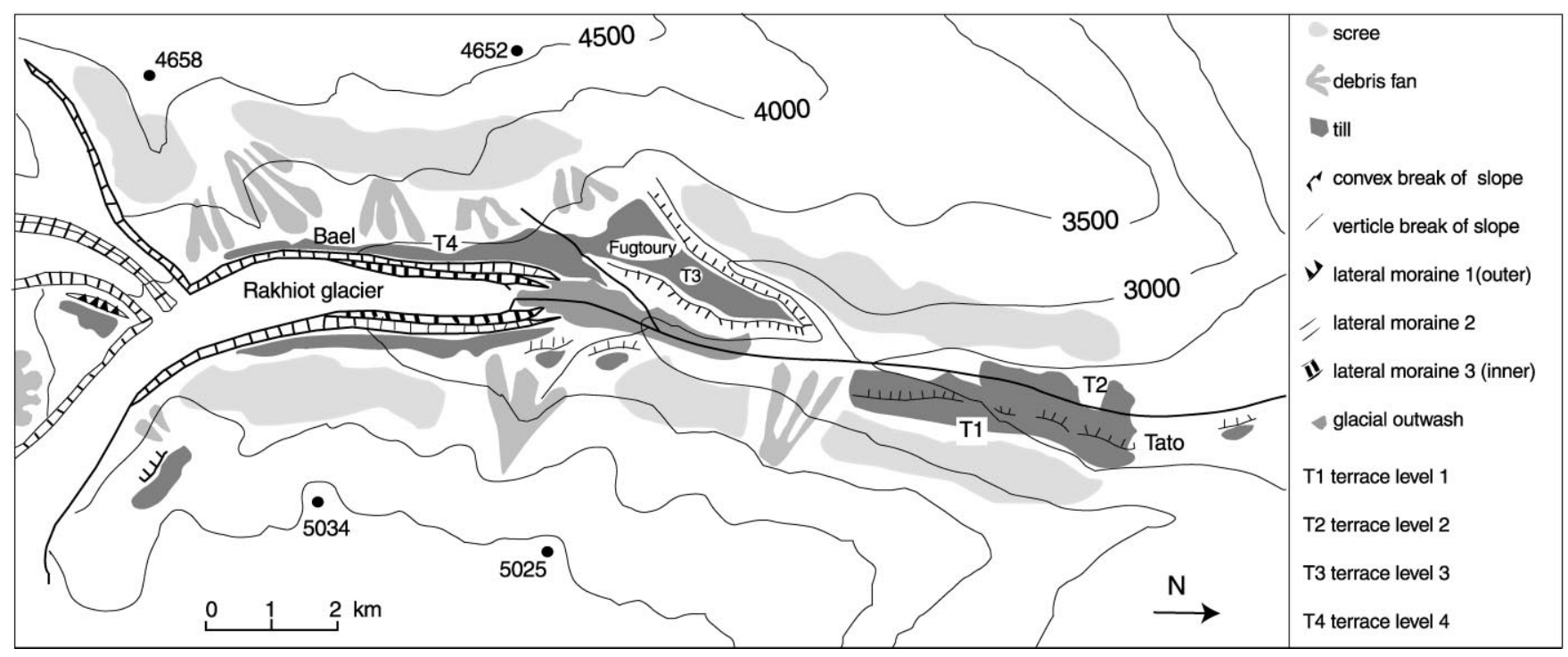

Fig. 13. Geomorphological map of the Rakhiot valley.

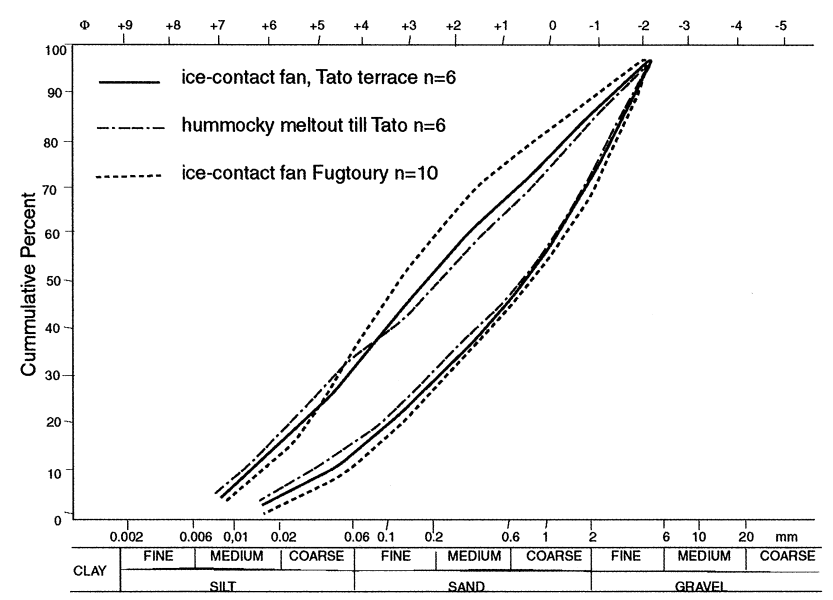

Fig. 14. Particle size distribution envelopes for glacial deposits in the Rakhiot valley.

of pitting and splitting (Fig. 15). This suggests that these units are of comparable age, being the oldest glacial deposits in the Rakhiot Valley.

\subsection{Fugtoury terrace (T3)}

This unit is situated $2 \mathrm{~km}$ south and upstream of Tato where it forms a distinct high terrace, $250 \mathrm{~m}$ above the valley floor (Fig. 13). It extends part of the way across the valley but is dissected by the Rakhiot River to produce steep cliffs with earth columns. It appears to be composed entirely of glacial material as it is poorly sorted, and contains angular clasts up to $2 \mathrm{~m}$ in length within a fines-rich matrix.

Localized boulder beds up to $5 \mathrm{~m}$ in length, exhibiting crude down-slope stratification, are exposed in the earth column cliffs throughout the unit. Localized stratified sandy deposits are also present and these were interpreted in the field on the basis of their well-sorted and bedded structures as being low-energy glaciofluvial sediments. The sediment is texturally massive and poorly sorted. Where stratification exists it is locally variable, with clast fabrics subparallel to it, strongly suggesting that this is an ice-contact deposit. As such, it was laid down when the ice front was close to Fugtoury.

Relative dating measures were applied to the larger clasts at the surface of this unit. The strong brown rock varnish, and the degree of splitting and pitting of boulders (Fig. 15) are similar throughout the whole unit, indicating that all deposits within the unit are of similar age. The degree of weathering of the boulders is markedly less than those observed around Tato. For this reason, the Fugtoury terrace is considered to be younger than the Tato units, and thus represent a distinct stage of glacial deposition following retreat of the ice from Tato. As in the Tarshing valley, the available evidence is not sufficient to show whether the Fugtoury terrace was formed during a readvance of the glacier or by a still-stand punctuating general glacial retreat.

\subsection{Bael unit (T4)}

This unit exists on both sides of the valley as a fill between the glacier and the valley sides. It appears in the field to be composed of glacial material, overlain on the valley sides by colluvial debris flows. These debris flow deposits have distinctive morphologies, with channels and levees descending from the valley slopes to form fans on the surface of the glacial material (Fig. 13). The diamicton was classified as glacial in the field on the basis of its poorly sorted texture with large angular clasts supported in a fine matrix. The clasts are less angular than 

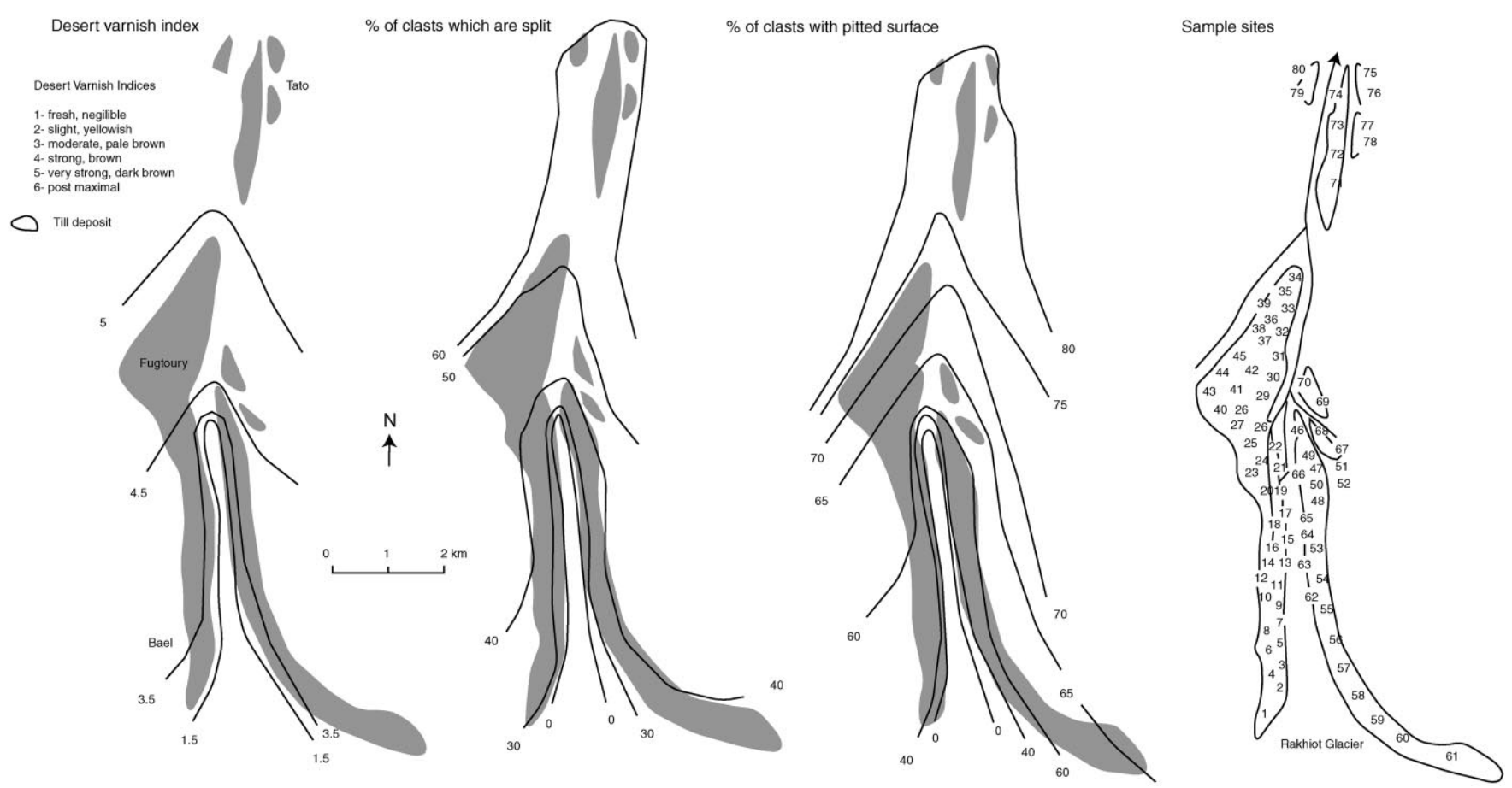

Fig. 15. Relative dating of terraces and moraines along the Rakhiot valley between Bael and Tato.

those of the debris flow deposits. Particle size analysis of samples of matrix from within the till confirmed it to be texturally massive with a rather narrow size distribution. Relative dating measures were applied to the clasts on the surface of this lateral moraine, down the length of the unit. The results shown in Fig. 15 indicate that these clasts are in the same weathering state throughout the deposit, suggesting that this lateral moraine is all of one age. These results also suggest that the moraine is younger that the glacial deposits at Fugtoury and Tato (Fig. 15).

\subsection{Contemporary lateral moraines $(T 5)$}

Large, clearly defined lateral moraines extend all around the present Rakhiot Glacier margin as an inset sequence paralleling the glacier. This clearly defined morainic series suggests an episodic retreat of the glacier. The clasts within the moraine are angular and are contained within a fines-rich matrix. Post-depositional weathering and reworking of the outer lateral moraines has reduced their formerly sharp crests to low, rounded ridges. Large clasts on the surface of these outer moraines exhibit a moderate pale brown rock varnish, whilst those of the inner moraines have a slight pale yellow varnish consistent with the fact that they are among the youngest glacial deposits in the Rakhiot valley.

In summary, the available evidence from the Rakhiot valley suggests that the deposits are the product of two distinct periods of relative stability of the glacier terminus during its recession: at Tato and Fugtoury. A schematic model of the development of the observed sedimentary sequences, incorporating two still-stands during retreat, is shown in Fig. 16. Stage I of this model represents the still-stand of the glacier at Tato with characteristic icecontact material. Stage II shows glacier retreat producing meltout tills from ice wastage along the valley floor until the next still-stand at Fugtoury where ice-contact material again accumulated. Further ice wastage in stage III occurred until the glacier reached its present position, large lateral moraines being associated with punctuations in the general retreat. It must be reiterated, however, that the observed evidence does not allow a clear distinction to be made between two still-stand positions or two short but distinct advances.

\section{Rama valley}

The Rama valley trends NE-SW with the Sachen glacier at its head. Three main terraces are present (Fig. 17) and will be described in detail.

\subsection{The astor terrace $(T 1)$}

At Astor, in the lower part of the valley, a cone shaped deposit $1.5 \mathrm{~km}$ across at its lower end, $1.5 \mathrm{~km}$ in length and over $250 \mathrm{~m}$ thick, rises above the Astor valley floor. This was interpreted in the field as a glacial deposit formed in an ice-contact position, as it could be seen to exhibit features described in such deposits by previous workers (Owen and Derbyshire, 1989). These include 


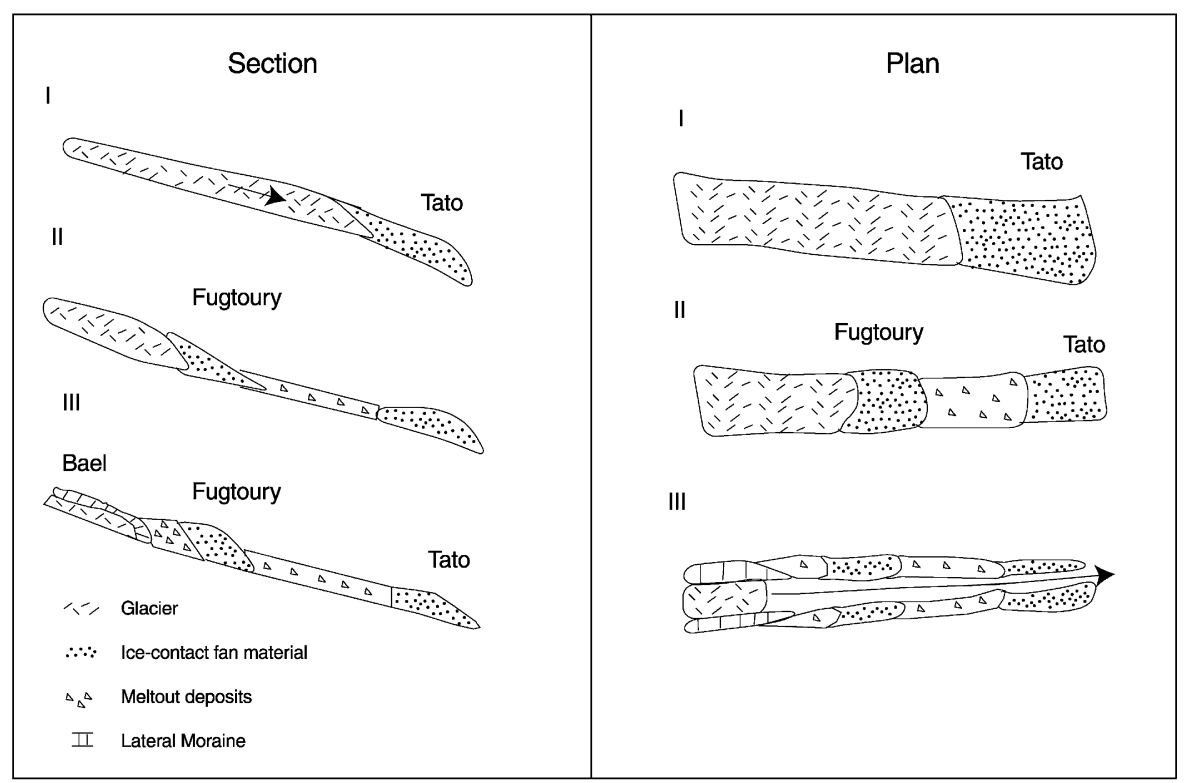

Fig. 16. Schematic development of Rakhiot valley. (I) Still-stand of ice at Tato gives rise to accumulation of ice-contact material at northern end of valley. (II) Glacier retreat up-valley to Fugtoury produces meltout deposits along valley floor, second still-stand gives rise to accumulation of ice-contact material at Fugtoury. (III) Further glacier retreat up-valley punctuated by minor still-stand/readvances producing large lateral moraines. Deposits dissected by Rakhiot glacier meltwater.

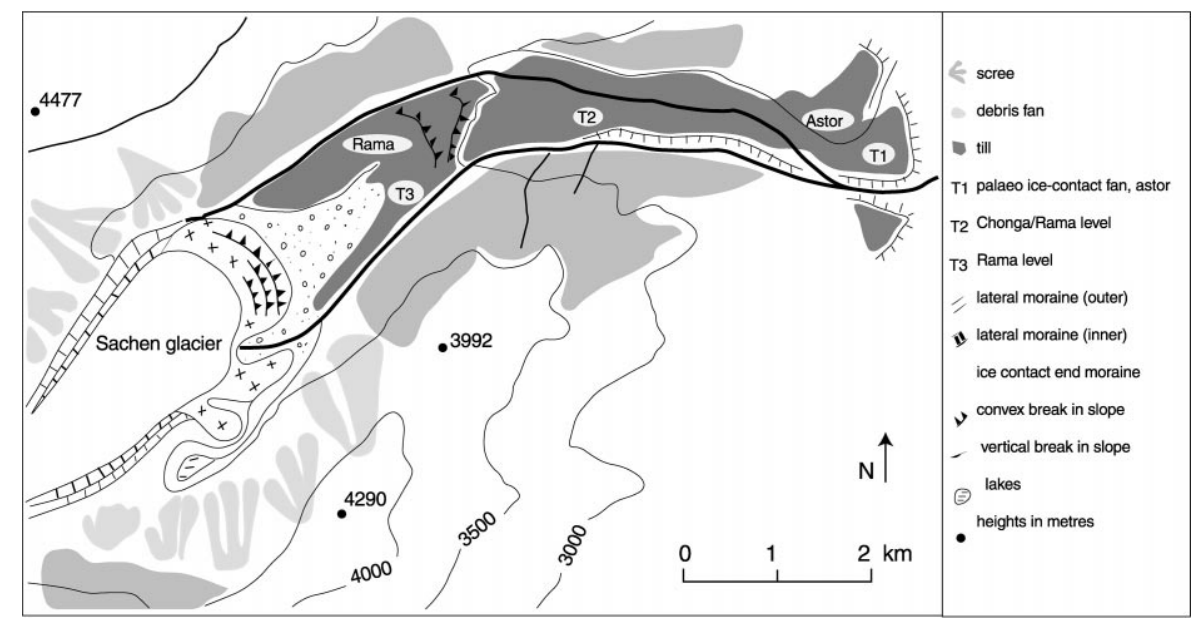

Fig. 17. Geomorphological map of Rama valley.

massive and crudely (meter-thick) stratified diamicton interstratified with glaciofluvial sands and gravels (Fig. 18). The diamictons contain large angular clasts within a fines-rich matrix. Particle size analysis shows the glacial diamicton to be generally massive in texture, but with localized areas in which grain size is very variable (Fig. 19). Microfabric analysis of the matrix shows the diffuse nature of the fabric with localized areas of strong orientation (Table 1). These characteristics are consistent with an ice-contact origin for these fans. As such, they mark a former ice terminus in the vicinity of Astor.

\subsection{Rama terrace levels (T2) and (T3)}

Up valley from Astor two distinct terrace levels can be seen (Fig. 17). These appear to be composed of tills, being poorly sorted and containing large angular clasts set in a fine matrix, characteristics consistent with an origin from local ice wastage, associated with glacial retreat. Throughout these deposits, no significant textural distinctions were observed between the terrace units. Particle size analysis revealed that the glacial sediments are very similar throughout, but that material taken from breaks in slope between the terrace levels (the base of the 


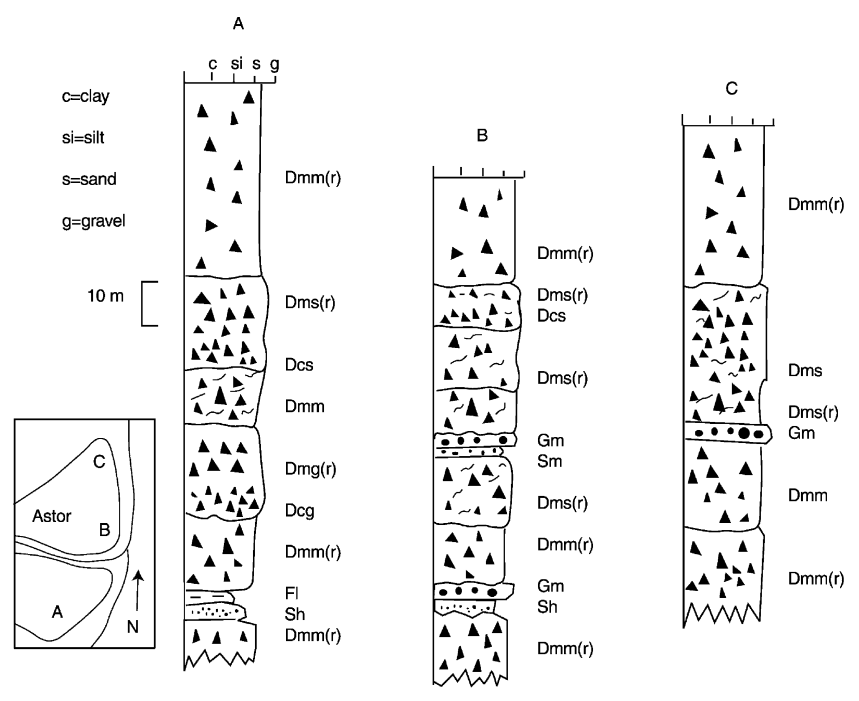

Fig. 18. Vertical sedimentary logs through deposits of the Astor icecontact fan. Lithofacies coding after Eyles et al. (1983). (Dmm - massive matrix-supported diamicton; Dms — stratified matrix-supported diamicton; Dcm - massive clast-supported diamicton; Dcs - stratified clast-supported diamicton; Dmg — graded matrix-supported diamicton; Fl - silts with fine lamination often with minor fine sand and very small ripples; $\mathrm{Sh}$ - sand with horizontal planar bedding; Gt - gravels with trough cross-bedding; Gm - massive clast-supported gravel; (r) - evidence of resedimentation; (s) - sheared).

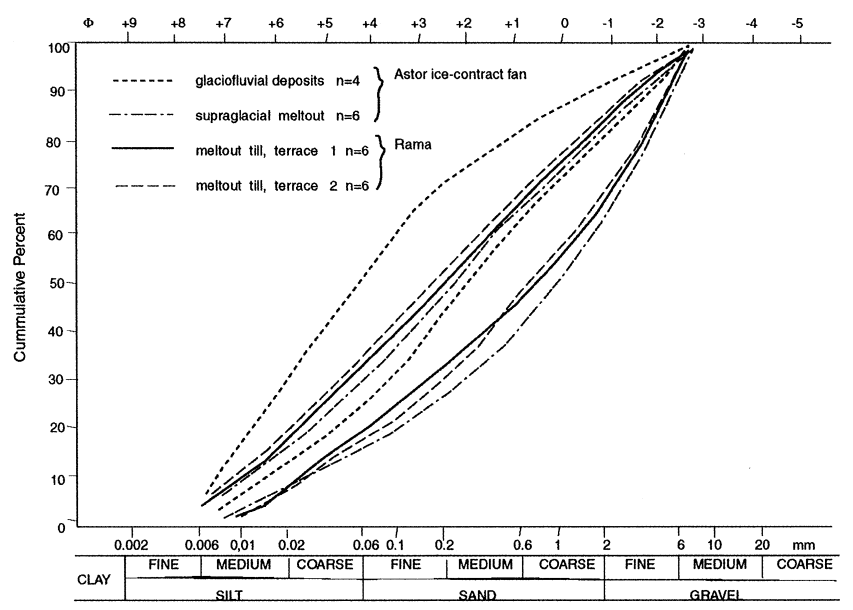

Fig. 19. Particle size distribution envelopes for glacial deposits in the Rama valley.

terrace risers) show greater variability than those within the terraces. At the microscopic scale, pseudoshears are present with highly variable orientations and dips (Table 1), features which are consistent with meltout (Owen, 1991) and typical of ice-front deposits (Derbyshire et al., 1985; Boulton, 1986). The lack of good sections prevented further and more intensive investigation of this series of glacial deposits. Around the present terminus, a new terrace level can be seen in the process of formation as an end moraine, rising $50 \mathrm{~m}$ above the
Rama glacial terrace (Fig. 17). This ice-contact end moraine can be considered as an analogue of the Rama valley terraces. The terraces probably formed by meltout during a glacier retreat which was punctuated by periods of still-stand, during which ice-contact deposition was concentrated over a short valley reach. This sequence of events could well have produced the distinctive terrace levels which can be seen along the valley, the steep breaks in slope marking successive positions of the glacier snout. If this interpretation is correct, the Rama valley deposits probably represent at least two periods of ice stagnation.

\section{Discussions and conclusions}

Evidence from the Nanga Parbat region as a whole indicates that, at one or more times in the Pleistocene, an extensive glacier system occupied the valleys of the massif with ice fronts more than $15 \mathrm{~km}$ down-valley of their present positions. The only firm evidence of distinct Pleistocene glacial advances lies in the glacial landforms of the Astor valley where two separate glacial advances took place. Extension of ice into this valley would have required a substantial lowering of regional temperatures in line with Pleistocene events in other parts of the northwest Himalaya. Elsewhere in the massif, glacial evidence suggests less extensive glaciation with snout positions no more than $12 \mathrm{~km}$ beyond those of the present. Although it appears that the depositional evidence of earlier Pleistocene glaciations in these high valleys has been destroyed by subsequent glacial and slope activity, erosional evidence of extensive glaciation in the form of truncated spurs, hanging valleys, steep valley sides and over-deepened trunk valleys is present. Trimline evidence is vague because of the intense slope processes that have persisted to the present day.

The evidence presented in this study clearly shows that the deposits present in the high valleys of the Nanga Parbat Massif mark a waning series of glacier fronts, the glaciers becoming more topographically constrained with time, leading to the present extreme example of this state. Distinct ice front accumulations, marking either still-stands or pulsed advances, are clear in the glacial deposits within the high valleys. The intermediate glacial deposits owe their origin to glacier stagnation and downwasting. In all valleys the lowermost deposits mark the outermost ice-front position and thus are the oldest. A comparison between the relative dating results from the Rupal and Rakhiot valleys, which lie opposite sides of the Nanga Parbat summit, suggests a broadly synchronous series of events of regional status. The clasts within the lowest (oldest) glacial deposits appear to exhibit similar degrees of weathering and thus it can be reasonably inferred that they are of a similar age. Wastage of the glaciers up-valley can be seen in all cases to have been punctuated by at least two still-stands or 


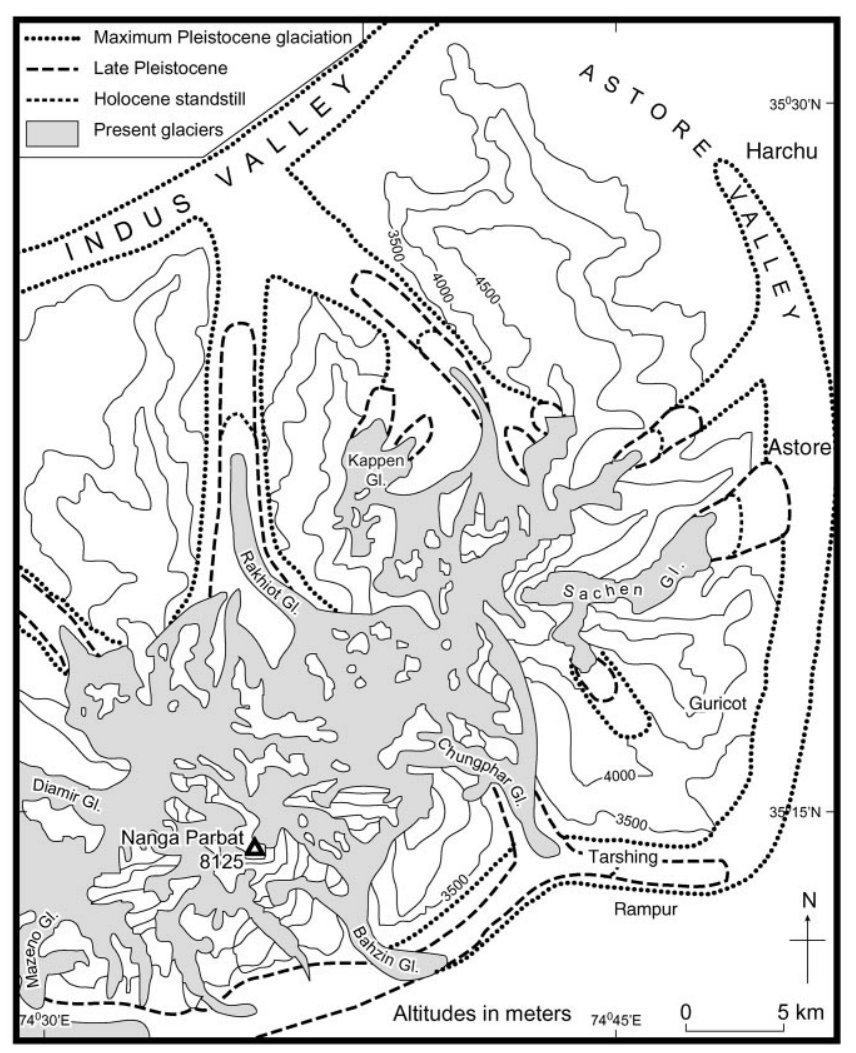

Fig. 20. Proposed ice extents during the late Quaternary for the Nanga Parbat massif.

readvances in each valley system followed by further glacier retreat. The lack of unequivocal evidence of glacier advances during general retreat may render stillstand the more likely explanation. Clasts within the extensive meltout tills formed during wastage events show similar degrees of weathering throughout. This suggests that retreat between stages were relatively rapid. In contrast, the thickness of the still-stand deposits suggests that these periods were relatively lengthy, or that the glaciers contained large volumes of debris.

A tentative outline of Quaternary glaciation of the Nanga Parbat Massif is shown in Fig. 20. Evidence from the Nanga Parbat glacial systems does not indicate that glacial readvances took place at any stage following a glacial maximum in the upper Pleistocene. Rather, glacial retreat from this maximum was merely punctuated by periods of still-stand. Such still-stands in glacial conditions could have been brought about by factors other than reversal of the regional warming trend envisaged for this region through the Quaternary (Kick, 1980; Kalvoda, 1981). For example, increases in glacial accumulation could result from increases in precipitation brought about by a changing regional wind system, such as fluctuations of the monsoon (Mayewski and Jeschkte, 1979; Holmes, 1988). Also, uplift in the form of tectonism or isostatic rebound could increase glacial accumulation by the promotion of orographic rainfall (Molnar and
England, 1990) and provision of more topographically efficient accumulation areas. Such changes in glacier accumulation might well prove sufficient to bring about a standstill in the wastage of ice. Not until the sedimentary sequences in the valleys of regions such as the Nanga Parbat Massif are rigorously dated will it be possible to use them to improve understanding of the interaction between uplift and climatically driven glacial changes.

The timing of glaciation throughout the Nanga Parbat Massif has still to be adequately resolved. Sloan et al. (1998) applied the cosmogenic ${ }^{3} \mathrm{He}$ surface exposure technique to garnets in moraine boulders in the Rakhiot valley. These gave tentative dates for the oldest moraines of $\sim 56 \mathrm{ka}$ and a younger set of moraines at $\sim 8 \mathrm{ka}$. Furthermore, using optically stimulated luminescence methods Richards et al. (2000a) dated glaciogenic sediments in the middle Indus valley, the Swat Himalaya and the Rampur valley. These show that several glaciations occurred during the last glacial cycle with the maximum advance during oxygen Isotope Stage 3 (Fig. 1a). The dates on the Rampur moraines showed that ice still occupied the Tarshing valley at $15.1 \pm 4.4 \mathrm{ka}$. These data support the view that the maximum extent of glaciation in Nanga Parbat occurred during the early part of the last glacial cycle. At least two readvances or periods of stagnation during late Pleistocene times, and at least three limited advances during the Holocene followed the local Last Glacial Maximum.

It is reasonable to assume that, since the end of the Pleistocene, a significant change in the glacial extent and regime in Nanga Parbat has taken place, from one eroding mostly subglacially to one in which supraglacial debris is dominant. Evidence indicating such a shift can be seen throughout the Nanga Parbat Massif where the broad valleys with their steep valley sides and truncated spurs can be ascribed directly to erosion by extensive, thick glaciers in the late Pleistocene. Following their wastage, the voluminous glacial deposits in the valleys provide evidence of a greatly increased input of supraglacial debris, and a comparative decline in the subglacial component of the system. This evidence shows that with the end of the Pleistocene, there occurred both a change in glacial extent and a change in the type of glacial system operating in this region.

\section{Acknowledgements}

Thanks go to the NERC (Award GT4/89/GS/053) for funding this research and $\mathrm{Kim} \mathrm{Li}$ for drafting the figures.

\section{References}

Benn, D.I., 1990. Scottish Lateglacial moraines: debris supply, genesis and significance. Unpublished Ph.D. Thesis, University of St. Andrews. 
Boulton, G.S., 1977. Ice contact position deposition; a multiple till sequence by a Late Devensian Welsh Ice Cap. Cambria 4, 10-31.

Boulton, G.S., 1978. Boulder shapes and grain-size distributions of debris as indicators of transport paths through a glacier and till genesis. Sedimentology 25, 773-799.

Boulton, G.S., 1986. Push-moraines and glacier-contact fans in marine and terrestrial environments. Sedimentology 33, 677-698.

British Standards Institute, 1975. BS1377: Methods of Test for Soils for Civil Engineering Purposes. British Standards Institute, London.

Derbyshire, E., Edge, M.J., Love, M., 1985. Soil variability in some glacial diamicts. In: Forde, M.C. (Ed.), Glacial Tills 85. Proceedings of the International Conference on Construction in Glacigenic Tills and Boulder Clays. Edinburgh Engineering Technic Press, Edinburgh, pp. 169-175.

Derbyshire, E., Li Jijun, Perrott, F.A., Xu Shuying, Waters, R.S., 1984. Quaternary glacial history of the Hunza Valley, Karakoram Mountains, Pakistan. In: Miller, K. (Ed.), International Karakoram Project. Cambridge University Press, Cambridge, pp. 456-495.

de Jong, M.G.G., Rappol, M., 1983. Ice-marginal debris-flow deposits in western Allgau, southern West Germany. Boreas 12, 57-70.

Dowdeswell, J.A., Hambrey, M.J., Wu, R., 1985. A comparison of clast fabric and shape in late Precambrian and modern glacigenic sediments. Journal of Sedimentary Petrology 55, 691-704.

Eyles, N., Eyles, C.H., Miall, A.D., 1983. Lithofacies types and vertical profile models: an alternative approach to the description and environmental interpretation of glacial diamict and diamictite sequences. Sedimentology 30, 393-410.

Haldorsen, S., Shaw, S., 1982. The problems of recognizing melt-out till. Boreas 11, 261-277.

Holmes, J.A., 1988. Pliocene and Quaternary environmental change in Kashmir, north west Himalaya. Unpublished Ph.D. Thesis, University of Oxford, 552pp.

Hoppe, G., 1952. Hummocky moraine regions with special reference to the interior of Norbotten. Geografiska Annaler 41, 1-71.

Kalvoda, J., 1981. Review of the Quaternary glaciation in the Himalayas. In: Sibrava, V., Shotton, F.W., (Ed.), Quaternary Glaciations in the Northern Hemisphere. International Geological Correlation Project, 73/1/24 Report, Vol. 6, pp. 163-185.

Kick, W., 1980. Material for a glacier inventory of the Indus drainage basin - the Nanga Parbat massif. In: World Glacier Inventory. Proceedings of the Riederalp Workshop, 1978. 1AHS-AISH Publication, Vol. 126, pp. 105-109.

Lawson, D.E., 1979a. A comparison of the pebble orientation in ice and deposits of the Matanuska glacier. Alaska. Journal of Geology 87, 629-645.

Lawson, D.E., 1979b. Sedimentological analysis of the western terminus region of the Matanuska glacier. Alaska. CRREL Report 79-9, 122 pp.

Mayewski, P.A., Jeschkte, P.A., 1979. Himalayan and trans-Himalayan glacier fluctuations since AD 1812. Arctic and Alpine Research 11 (3), 267-287.

McGown, A., Derbyshire, E., 1977. Genetic influences on the properties of tills. Quarterly Journal of Engineering Geology 10, 389-410.

Molnar, P., England, P., 1990. Late Cenozoic uplift of mountain ranges and global climate change: chicken or egg?. Nature 346, 29-34.

Owen, L.A., 1988. Terraces, uplift and climate, the Karakoram Mountains, Northern Pakistan. Unpublished Ph.D. Thesis, University of Leicester, 399pp.
Owen, L.A., 1989. Neotectonics and glacial deformation in the Karakoram Mountains and Nanga Parbat Himalaya. Tectonophysics 163, 227-265.

Owen, L.A., 1991. Mass movement deposits in the Karakoram Mountains: their sedimentary characteristics, recognition and role in Karakoram landform evolution. Zeitschrift für Geomorphologie N.F. 35, 401-424.

Owen, L.A., 1994. Glacial and non-glacial diamictons in the Karakoram Mountains and Western Himalayas. In: Warren, W.P., Croot, D.G. (Eds.), Formation and Deformation of Glacial Deposits. A.A. Balkema, Rotterdam, pp. 9-28.

Owen, L.A., Derbyshire, E., 1989. The Karakoram glacial depositional system. Zeitschrift für Geomorphologie N.F. 76, 33-73.

Owen, L.A., Benn, D.I., Derbyshire, E., Evans, D.J.A., Mitchell, W.A., Richardson, S., 1996. The Quaternary glacial history of the Lahul Himalaya. Northern India. Journal of Quaternary Science 11 (1), $25-42$.

Owen, L.A., Mitchell, W., Bailey, R.M., Coxon, P., Rhodes, E., 1997. Style and timing of Glaciation in the Lahul Himalaya, northern India: a framework for reconstructing late Quaternary palaeoclimatic change in the western Himalayas. Journal of Quaternary Research 12 (2), 83-110.

Porter, S., 1970. Quaternary glacial record in Swat Kohistan. West Pakistan. Geological Society of America Bulletin 81, 1421-1446.

Powers, M.C., 1953. A new roundness scale for sedimentary particles. Journal of Sedimentary Petrology 23, 117-119.

Richards, B.W.M., Owen, L.A., Rhodes, E.J., 2000a. Timing of Late Quaternary glaciations in the Himalayas of Northern Pakistan. Journal of Quaternary Science, in press.

Richards, B.W.M., Ben, I.D., Owen, L.A., Rhodes, E.J., Spencer J.Q., 2000b. Timing of Late Quaternary glaciations south of Mount Everest in the Khumbu Himal, Nepal. Geological Society of America Bulletin, in press.

Sharma, M.C., Owen, L.A., 1996. Quaternary glacial history of the Garhwal Himalaya. India. Quaternary Science Reviews 15, $335-365$.

Shaw, J., 1986. Discussion: Lithofacies types and vertical profile models. Sedimentology 33, 151-155.

Shiraiwa, T., Watanabe, T., 1991. Late Quaternary fluctuations in the Langtang valley, Nepal Himalaya, reconstructed by relative dating methods. Arctic and Alpine Research 23, 404-416.

Shroder Jr., I.F., Khan, N.I.S., Lawrence, R.D., Madin, I.P., Higgins, S.M., 1989. Quaternary glacial chronology and neotectonics in the Himalaya of northern Pakistan. Geological Society of America Special Paper 232, 275-294.

Shroder, J.F., Owen, L.A., Derbyshire, E., 1993. Quaternary glaciation of the Karakoram and Nanga Parbat Himalaya. In: Shroder, J.F. (Ed.), Himalaya to the Sea: Geology, Geomorphology and the Quaternary. Routledge, London, pp. 132-158.

Sloan, V., Phillips, W.M., Shroder, J.F., Sharma, P., Rendell, H., 1998. Asynchronous maximum advances of mountain glaciers in the Pakistan Himalaya. GSA Abstracts with Programs 30 (7), A-229.

Tucker, M.E., 1982. The field description of sedimentary rocks. In: Geological Society of London Handbook Series, Vol. 1. Open University Press, Milton Keynes, 12pp.

Wentworth, C.K., 1922. A scale of grade and class terms for clastic sediments. Journal of Geology 30, 377-392.

Zingg, T., 1935. Beitrag zur Schotteranalyse, Scweizerische. Mineralogische und Petrographische Mitteilungen 15, 39-140. 